\title{
1 Pre-existing normal faults have limited control on the 2 rift geometry of the northern North Sea
}

3

Johan S. Claringbould ${ }^{1 *}$, Rebecca E. Bell ${ }^{1}$, Christopher A-L. Jackson ${ }^{1}$, Robert L. Gawthorpe ${ }^{2}$, Tore Odinsen ${ }^{3}$

${ }^{1}$ Basins Research Group (BRG), Department of Earth Science and Engineering, Imperial College, London, SW7 2BP, UK

${ }^{2}$ Department of Earth Science, University of Bergen, Allégaten 41, 5007 Bergen, Norway

${ }^{3}$ Statoil ASA, Sandslihaugen 30, 5254 Sandsli, Norway

*Corresponding author: Earthquake Research Institute, The University of Tokyo, 1-1-1 Yayoi, Bunkyo-ku, Tokyo, 113-0032, Japan.

Email address: jsclaring@eri.u-tokyo.ac.jp

\section{Abstract}

Many rifts develop in response to multiphase extension with numerical and physical models suggesting that reactivation of first-phase normal faults and rift-related variations in bulk crustal rheology control the evolution and final geometry of subsequent rifts. However, many natural multiphase rifts are deeply buried and thus poorly exposed in the field and poorly imaged in seismic reflection data, making it difficult to test these models. Here we integrate recent $3 \mathrm{D}$ seismic reflection and borehole data across the entire East Shetland Basin, northern North Sea, to constrain the long-term, regional development of this multiphase rift. We document the following key stages of basin development: (i) pre-Triassic to earliest Triassic development of multiple sub-basins controlled by widely distributed, NNW- to NE-trending, east- and west-dipping faults; (ii) Triassic activity on a single major, NE-trending, westdipping fault located near the basins western margin, and formation a large 
half-graben; and (iii) Jurassic development of a large, E-dipping, N- to NEtrending half-graben near the eastern margin of the basin, which was associated with rift narrowing and strain focusing in the Viking Graben. In contrast to previous studies, which argue for two discrete periods of rifting during the Permian-Triassic and Late Jurassic-Early Cretaceous, we find that rifting in the East Shetland Basin was protracted from pre-Triassic to Cretaceous. We find that, during the Jurassic, most pre-Jurassic normal faults were buried and in some cases cross-cut by newly formed faults, with only a few being reactivated. Previously developed faults thus had only a limited control on the evolution and geometry of the later rift. We instead argue that strain migration and rift narrowing was linked to the evolving thermal state of the lithosphere, an interpretation supporting the predictions of lithospherescale numerical models. Our study indicates that additional regional studies of natural rifts are required to test and refine the predictions of physical and numerical models, more specifically, our study suggests models not explicitly recognising or including thermal or rheological effects might over emphasise the role of discrete pre-existing rift structures such as normal faults.

Keywords: multiphase rift, pre-existing fault, fault reactivation, rift narrowing, rift geometry, East Shetland Basin

\section{Introduction}

Continental extension marks the first stage of ocean basin formation, being associated with normal faulting and the development of rift basins (e.g. Nagel 
and Buck, 2007). Because continental breakup is protracted (i.e. several tens of millions of years; e.g, Ziegler and Cloetingh, 2004), and the related extensional forces are complex, many rifts are products of not one, but multiple phases of extension (e.g., the northern North Sea, Færseth, 1996; the Gulf of Thailand, Morley et al., 2004; and the Galicia rifted margin, Reston, 2005). Unlike polyphase rifts, in which the rheologic character changes due to progressive deformation and thinning during a single extension phase (e.g., fault block rotation and locking, Reston, 2005; ductile to brittle deformation, Lavier and Manatschal, 2006), multiphase rifts have been exposed to multiple episodes of extension (with or without a change in extensional direction), with extension phases possibly separated phases of quiescence.

The geometry and evolution of such multiphase rifts, especially during the latter stages of their development, may thus be controlled by reactivation of discrete, pre-existing, upper crustal structures, such as normal faults, or more pervasive fabrics developed during earlier rift or orogenic periods (e.g., Badley et al., 1988; Strecker et al., 1990; Coward, 1993; Færseth, 1996; Keep and McClay, 1996; Odinsen et al., 2000; Gawthorpe et al., 2003; Morley et al., 2004; Bellahsen and Daniel, 2005; Cowie et al., 2005; Reston, 2005; Henza et al., 2010, 2011; Nixon et al., 2014, Whipp et al., 2014; Duffy et al., 2015; Phillips et al., 2016). However, because sedimentary basins formed during the early stages of multiphase rifting are progressively buried and structurally overprinted during later stages of rifting, it can be difficult to assess the role pre-existing faults play in controlling subsequent rift geometry. In some cases, older faults are abandoned and may in fact be cross-cut by newly formed 
structures (e.g., Lee and Hwang, 1993; Thomas and Coward, 1995; Reston, 2005; Tomasso et al., 2008; Bell et al., 2014).

Scaled physical models provide useful insights into the geometry and kinematics of upper-crustal, fault networks during multiphase rifts, predicting pre-existing faults are likely to be at least partly reactivated if the stretching direction changes by $<45^{\circ}$ between extension events (Henza et al., 2010). Although powerful, the majority of these models tend to focus on relatively small fault networks and do not incorporate the superimposed effects of lithosphere-scale heterogeneities (e.g. rheology and temperature). Unlike crustal-scale physical models, lithosphere-scale numerical models can explicitly capture variations in lithosphere properties at a scale appropriate to multiphase rifts associated with continental breakup. Lateral variations in lithosphere rheology and temperature, which may be imposed by and inherited from earlier phases of stretching, may also play a key role in controlling the location and style of rifting (e.g. Buck et al, 1999; Odinsen et al., 2000; Burov and Poliakov, 2001; Huismans et al., 2001; Behn et al., 2002; Ziegler and Cloetingh, 2004; Cowie et al., 2005; Huismans and Beaumont, 2007; Nagel and Buck, 2007; Naliboff and Buiter, 2015). For example, Naliboff and Buiter (2015) use finite difference models to show that, if the period of tectonic quiescence between rift phases is sufficiently long, then the integrated strength of the first-phase rift axis site can recover, leading to largescale rift migration and the abandonment of first-phase faults. However, most lithosphere-scale models are of insufficient spatial resolution $(>1 \mathrm{~km})$ to allow direct investigation of the impact of individual pre-existing faults on the 
geometry and evolution of subsequent fault networks and the rift basins they control.

Outcrop studies can reveal the geometry and kinematic development of large rift-related fault arrays (i.e., a kinematically linked group of faults that are 10's to $100 \mathrm{~km}$ of length) at a relatively high-level of spatial and temporal precision (e.g., Strecker et al., 1990; Gawthorpe et al., 2003; Morley et al., 2004). However, such studies are typically limited by the quantity and quality of outcrop, with structures and stratigraphy associated with only one rift stage being exposed. In contrast, subsurface studies utilising long (10's to $100 \mathrm{~km}$ ), widely spaced ( $>5 \mathrm{~km}$ ) 2D seismic profiles allow us to define the basin-scale geometry of structures associated with individual tectonic phases in multiphase rifts, but these lack the spatial detail needed to investigate how pre-existing faults behave on the scale of individual fault systems (i.e., kinematically linked group of faults that are 1-to several 10's of km long) (e.g., Badley et al., 1988; Coward, 1993; Thomas and Coward, 1995; Færseth, 1996; Reston, 2005). More insightful are subsurface studies using 3D seismic reflection data (e.g., Tomasso et al., 2008; Nixon et al., 2014, Whipp et al., 2014; Duffy et al., 2015). These studies are able to highlight the sometimes subtle influence of pre-existing faults on subsequent fault system development. However, these typically only consider a limited time-interval ( $<50 \mathrm{Myr}$ ) due to the limited depth of imaging, thus do not cover the full multiphase rift history. Furthermore, as individual 3D surveys typically cover 126 only $\sim 500 \mathrm{~km}^{2}$, these studies are usually too small to assess the relative influence of lithospheric-scale processes. 
In this study we combine well log-tied 2D and multiple merged 3D seismic reflection surveys $\left(\sim 10,000 \mathrm{~km}^{2}\right)$ from the East Shetland Basin, northern North Sea (Fig. 1), to resolve the structure of the basin from pre-Triassic to the present day. Using these observations we address the following questions: (i) do pre-existing normal faults control rift geometry?; and (ii) does the lithosphere thermal and rheological state and structure influence rift geometry?. By addressing these questions, we test the predictions of physical and numerical models of multiphase rifting. Moreover, unlike most previous studies (see above), our extensive, high-quality dataset allows us to document how pre-existing normal faults throughout a regional fault array accommodate later extension.

\section{Geological setting}

The East Shetland Basin is located in the northern North Sea, on the western flank of the North Viking Graben (Fig. 1a). The present day geometry of the East Shetland Basin is dominated by structures related to the last major phase of rifting during the Middle-to-Late Jurassic. These structures comprise $\mathrm{N}$ - to NE-trending, east-dipping normal faults (Cormorant, Pelican, Heather, Murchison, Osprey, Hutton, Ninian, Statfjord, Brent, Strathspey, Alwyn, and Tordis faults) bounding $60-75 \mathrm{~km}$ long, $15-25 \mathrm{~km}$ wide half-grabens in the middle and eastern part of the East Shetland Basin (Fig. 1c). The East Shetland Platform lies along the western margin of the East Shetland Basin, forming a high that is bounded by two major east-dipping faults (Hudson and West Margin faults), whereas the Tern-Eider Ridge represents a prominent 
horst block located in the NW of the East Shetland Basin that is flanked by the Tern and Eider faults (Figs. 1c). The Magnus and Tern sub-basins lie to the north and south of the Tern-Eider Ridge, respectively, and the Ninian subbasin is located in the southern part of the East Shetland Basin (Fig. 1c).

Major phases of basement-involved extension occurred in the Late Palaeozoic to Mesozoic (e.g., Coward, 1990, \& 1993, Platt, 1995), with most authors agreeing that the northern North Sea experienced two discrete phases of extension in the Permian-Triassic and Middle-to-Late Jurassic (e.g., Badley et al., 1988; Lee and Hwang, 1993; Thomas and Coward, 1995; Færseth, 1996; Odinsen et al., 2000). The northern North Sea region is a moderately stretched rift, with low $\beta$-values i.e. stretching-values). Both extension phases were of approximately the same magnitude, reaching $\beta$ values of $\sim 1.4$ across the entire width of the northern North Sea, and 1.3 and 1.1 across the East Shetland Basin for the Permian-Triassic and Middle-toLate Jurassic, respectively (Roberts et al., 1995; Færseth, 1996; Odinsen et al., 2000).

Many authors suggest Late Palaeozoic to Mesozoic rift development was influenced, if not directly controlled, by the inherited Caledonian and Devonian structural framework, both in the East Shetland Basin (Coward, 1990 \& 1993; Rattey and Hayward, 1993; Platt, 1995; Thomas and Coward, 1995) and elsewhere (e.g., Doré et al. 1997), although this view has recently been challenged (e.g., Reeve et al., 2013). Reactivation of large Permian-Triassic faults during Middle-to-Late Jurassic rifting throughout the northern North Sea has been proposed (e.g., Badley et al., 1988; Færseth, 1996; Odinsen et al., 2000; Cowie et al. 2005). However, in the East Shetland Basin, an alternative 
interpretation, envisaging that Permian-Triassic faults are partly cross-cut and only partly reactivated during Middle-to-Late Jurassic rifting, is suggested (e.g., Lee and Hwang, 1993; Thomas and Coward, 1995; Tomasso et al., 2008). For example, Tomasso et al. (2008) propose that west-dipping Triassic normal faults developed in the SE of the East Shetland Basin and were subsequently cross-cut by new, large-displacement, east-dipping faults during Middle-to-Late Jurassic rifting. Tomasso et al. (2008) thus argue that preexisting Permian-Triassic faults did not control the Middle-to-Late Jurassic rift geometry, at least in this part of the basin.

\section{Data and methods}

\subsection{Seismic Reflection and Well Data}

We use a regional compilation of $2 \mathrm{D}$ and $3 \mathrm{D}$ time-migrated seismic reflection surveys collected between 2006 and 2012 (Fig. 1b). The 2D profiles cover the entire East Shetland Basin, and four partly overlapping, now-merged 3D seismic "merged-surveys" cover almost the whole western margin of the North Viking Graben (Fig. 1b). The 3D seismic reflection merged-surveys image to depths of 4.5 to $6.5 \mathrm{~s}$ TWT and have a $12.5 \times 12.5 \mathrm{~m}$ or $25 \times 25 \mathrm{~m}$ in-line and cross-line spacing, thus enabling detailed horizon and fault interpretations across much of the East Shetland Basin. The 2D profiles have a line spacing of $\sim 5 \mathrm{~km}$ and image to a depth of $\sim 8 \mathrm{~s}$ TWT, making them suitable for regional mapping and imaging deeper structures that are not always imaged by the $3 \mathrm{D}$ surveys. Data quality ranges from excellent for some of the $3 \mathrm{D}$ surveys to moderate for some of the 2D lines. In addition to the seismic reflection data, 
we use 82 exploration wells (Fig. 1b). These wells contain a standard wireline log suite, including gamma-ray (GR), density (RHOB), sonic (DT), checkshot, chrono- and lithostratrigraphic information, and final well reports. Thirty-nine wells terminate in the Jurassic, 37 in the upper part of the Triassic, and six penetrate the entire Triassic succession (Fig. 1b). The wells have been tied to the seismic data through the construction of synthetic seismograms (Figs. 1b, 2).

\subsection{Seismic interpretation}

We interpreted nine key horizons across the seismic dataset $\left(6800 \mathrm{~km}^{2}\right)$

(Figs. 2, 3). With the exception of the pre-Triassic horizons, all horizon interpretations are tied to wells (Figs. 1b, 2). The three pre-Triassic horizons are picked based on their continuous, high-amplitude seismic character; however, because they are not tied to well data, we cannot directly constrain their ages, hence they are named Pre-Triassic 1, 2, and 3.

To accurately determine the structure and evolution of the East Shetland Basin, structurally complex parts of the basin were interpreted on in-lines and cross-lines spaced at $250 \mathrm{~m}$, and on broadly NE- and NW-trending lines with $625 \mathrm{~m}$ spacing. Structurally simpler areas were interpreted on in-lines and cross-lines and/or on broadly NE- and NW-trending lines with $625 \mathrm{~m}$ spacing. All faults $(n=285)$ have been interpreted on at least two differently striking seismic lines, one of which trends approximately perpendicular to local fault strike. To improve our interpretation of the major faults (>25 km long) multiple horizontal (time) slices with 300 ms TWT (vertical) spacing were used. 


\subsection{Time-structure and isochron maps}

Time-structure maps of nine key horizons were used to calculate timethickness (isochron) maps of the eight key stratigraphic intervals. Timestratigraphic thickness maps are used as a proxy for syn-depositional fault activity because, in rift basins, variations in sediment thickness are predominantly controlled by syn-depositional normal faulting (e.g., McLeod et al., 2000; Childs et al., 2003; Bell et al., 2014). Time-depth data from 79 wells were used to determine an average time-depth relationship; this allowed us to convert thicknesses measured in TWT to metres with an c. $7 \%$ error. The principal thickness changes across faults are relatively large (>100 ms TWT across a fault) and therefore the thickness trends are unlikely to change significantly after depth conversion (cf. Tomasso et al., 2008). Furthermore, well data located on the footwall and hanging wall of major faults suggest that no underfilled basins are present in the study area: syn-kinematic sediments were deposited on both the hanging and footwall side of the fault.

\section{Sediment thickness distribution and depocentre evolution}

We have generated eight isochrons to illustrate temporal and spatial variations in the thickness of key stratigraphic units in the East Shetland Basin (Fig. 4). In addition to structural and stratigraphic geometries observed on the seismic profiles (Figs. 3, 5-8), these isochrons document the pre-Triassic to Cretaceous evolution of the principal rift-related depocentres. 


\subsection{Unit 1 (Pre-Triassic 1 - Pre-Triassic 2)}

Within Unit 1 a number of large ( 7 $\mathrm{km}$ long by up to $1400 \mathrm{~m}$ deep)

251 depocentres are observed in the Magnus, Tern and Ninian sub-basins and in 252 the hanging walls of the NE-trending, Eider and Pelican faults (Fig. 4a, 5). We

253 also observe thinner, but still substantial depocentres (up to $580 \mathrm{~m}$ ) in the 254 eastern part of the East Shetland Basin, adjacent to the Ninian and Cormorant 255 faults (Figs. 3a, 4a).

Depocentres that developed in the Tern sub-basin and hanging wall of the Pelican Fault during the previous time-interval continued to deepen during deposition of Unit 2 (Fig. 4b). The depocentre adjacent to the Ninian Fault, which defined the Ninian sub-basin, became segmented into two (Figs. 3c, $4 b, 6 a)$. A large depocentre formed in the hanging wall of the Eider Fault, burying the previously developed Magnus sub-basin (Figs. 3c, 4b). In the hanging wall of the large $\mathrm{N}$ - to NE-trending faults located in the middle of the East Shetland Basin (Cormorant, Murchison, Osprey, and Thistle faults), deposits of Unit 2 are relatively thin $(\sim 580 \mathrm{~m})$ and fairly isopachous. In the SE of the study area, we observe eastward thickening of this unit towards the crest of the Ninian footwall (Figs. 3b, c, 4b, 6a). 
271 Overall, Lower Triassic deposits are relatively thin in the East Shetland Basin,

272 gradually thickening eastward from $\sim 170$ to $520 \mathrm{~m}$, with a few small

273 depocentres in the hanging walls of several of the NE-trending faults (e.g.,

274 Pelican, Tern, and Eider faults, and Tern sub-basin; Figs. 3a, 4c). A major

275 depocentre does, however, occur on the western flank of the Ninian sub-

276 basin, with strata thickening westward (up to 1740 m thick) into the immediate

277 hanging wall of the Heather Fault (Figs. 3a, 4c).

4.4 Lomvi and Lunde formations (Middle-to-Upper Triassic) (ca. 245-201 Ma)

There is a clear change in sediment thickness patterns in Middle-to-Upper Triassic deposits described here (Fig. 4d) compared to the older seismic units (Figs. 4a, b, c). For example, in the western part of the basin, rather than being a broadly isopachous depocentre in the hanging wall of the Eider Fault, Middle-to-Upper Triassic deposits define a single, $\sim 840 \mathrm{~m}$ thick depocentre towards its southern end, and thinning northward towards the Magnus subbasin (down to $\sim 500 \mathrm{~m}$ ) (Figs. 3a, b, 4d, 5). In the footwall of the Eider Fault, Middle-to-Upper Triassic deposits thicken gradually eastward from $\sim 75 \mathrm{~m}$ on the Tern-Eider Ridge to $\sim 1200$ m south of the Tordis Fault (Figs. 3, 4d, 6, 7). Ma)

Another major change in sediment thickness distribution occurs during the deposition of the uppermost Triassic-to-Lower Jurassic deposits (Fig. 4e). 
Rather than defining a single, large, fault-bound depocentre located on the western margin of the East Shetland Basin, the uppermost Triassic-to-Lower Jurassic sediments vary little in thickness, and are characterized by tabular packages of sub-parallel reflections (Fig. 3, 4e, 8). We note that hanging wall packages are not wedge-shaped; rather, they are tabular like, albeit thicker than, their footwall counterparts resulting in step-wise, across-fault, thickness changes (Fig. 3, 4e, 8). Examples of this style of seismic-stratigraphic geometry occur adjacent to the Cormorant Fault ( 0 to $\sim 80 \mathrm{~m}$ thickness increase), the Ninian, Hutton, Murchison faults ( $\sim 75$ to $\sim 250 \mathrm{~m}$ thickness increase), and the Alwyn, Strathspey, Brent, and Statfjord faults $\sim 230$ to $\sim 475$ m thickness increase) (Figs. 3, 4e, 8).

\subsection{Dunlin Group (Lower Jurassic) (ca. 192-175 Ma)}

The trend of step-wise thickness changes of tabular stratigraphic packages across major $\mathrm{N}$ - to NE-trending faults is also observed in Lower Jurassic deposits of the Dunlin Group (Figs. 3, 4f). This is particularly well expressed across the Cormorant Fault ( 0 to $\sim 85 \mathrm{~m}$ thickness increase), Ninian and Hutton faults ( 0 to $\sim 225 \mathrm{~m}$ thickness increase), and Alwyn, Strathspey and Brent faults ( 190 to 440 m thickness increase).

\subsection{Brent Group (Middle Jurassic) (ca. 175-166 Ma)}

During deposition of the overall relatively thin (up to $350 \mathrm{~m}$ ) Brent Group (Fig. $4 \mathrm{~g}$ ), depocentres not only developed in the hanging walls of most of the $\mathrm{N}$ - to 
317 NE-trending, east-dipping faults (Cormorant, Ninian, Hutton, Alwyn, 318 Strathspey, Brent, and Statfjord faults), but also in the hanging walls of the 319 NE-trending Eider, Osprey, Murchison, and Heather faults (Figs. 3, 4g). 320 Thicknesses typically increase from $\sim 75 \mathrm{~m}$ on the footwalls of these faults to $321 \sim 180-360 \mathrm{~m}$ in the adjacent hanging wall depocentres (Fig. 4g).

At this time, large, $25 \mathrm{~km}$ long depocentres (up to $1550 \mathrm{~m}$ thick) developed in the hanging walls of the major $\mathrm{N}$ - to NE-trending faults across the entire width East Shetland Basin. Prominent wedge-shaped stratigraphic packages define these depocentres (Figs. 3, 4h, 6-8). It should be noted that the Base Cretaceous Unconformity (BCU), which is locally erosional over the footwall crests, defines the top of this stratigraphic package. Calculated thicknesses, thus, represent a minimum value in the footwall crests.

\section{Rift-related evolution of the East Shetland Basin}

The isochron maps allow us to document the distribution of sediment depocentres through time and space (Fig. 4). In combination with the crosscutting relationships between faults observed on the seismic data (Figs. 3, 58), these isochrons yield a detailed insight on the fault array development

338 throughout the East Shetland Basin (Fig. 9). From the pre-Triassic to Early

339 Triassic, multiple $10-20 \mathrm{~km}$ long, NNW- to NE-trending, west- and east- 
dipping faults were active in the middle and western parts of the East Shetland Basin (Figs. 4a-c, 9a-c). These faults formed the boundaries to several large depocentres ( 15 by $5 \mathrm{~km})$. The predominant strike of the active faults changed throughout this interval from NNW-SSE and N-S, to NE-SW (Figs. 4a-c, 9a-c), with the latter trend possibly reflecting reactivation of the NE-SW Caledonian structural grain (e.g., Coward, 1990 \& 1993; Rattey and Hayward, 1993; Platt, 1995; Thomas and Coward, 1995). We have no direct evidence of the presence of any basement fabrics in our dataset, however.

During the Middle-to-Late Triassic, strain was mainly focused in the west of the East Shetland Basin, being localised on the Eider Fault (Fig. 5, 9d). Elsewhere, syn-depositional faulting ceased, and strata gradually thickened eastward across the East Shetland Basin (Figs. 3, 4d, 6, 7), possibly due to activity on a large west-dipping fault located east of the study area near the axis of the North Viking Graben (e.g., Tomasso et al., 2008). An alternative interpretation is that this gradual eastward thickening of Middle-to-Upper Triassic sediments reflects thermal subsidence associated with PermianTriassic fault activity in the Horda Platform, which is located on the eastern margin of the North Viking Graben (Fig. 4a) (e.g., Badley et al., 1988; Lee and Hwang, 1993; Thomas and Coward, 1995; Færseth, 1996; Odinsen et al. 2001; Bell et al., 2014).

During the latest Triassic-to-Early Jurassic (Figs. 4e, f, 9e, f), strain mainly focused in the eastern part of the East Shetland Basin on long, $\mathrm{N}$ - to NEtrending, east-dipping faults that formed the boundaries to large, $\sim 50 \mathrm{~km}$ long and $\sim 25 \mathrm{~km}$ wide, half-grabens. Some of these faults represent reactivated pre-Jurassic normal faults (Figs. 4e, f, 6, 9e-g); however, others are new, 
relatively steep faults, cross-cutting older inactive and buried fault systems (Figs. 4e, f, 6-8, 9e-g). The change from relatively distributed faulting in the centre and western parts of the East Shetland Basin during the pre-Triassic and Triassic, to relatively focused faulting in the eastern part of the basin during the Early-to-Middle Jurassic, documents the onset of the Late Jurassic

370 Viking Graben rift system. Long, N-trending, east-dipping fault systems remain active during the Late Jurassic, and smaller faults mainly develop parallel to the larger faults (Figs. 4b, 7, 9f-h).

Most of the Late Jurassic faults originated no earlier than the latest Triassic, or were newly formed in the Late Jurassic (Fig. 4e, 9e). The main pre-Jurassic faults either: (i) became inactive, were buried, and, in some cases, were cross-cut by faults developed during the Jurassic (e.g., Ninian and Tern subbasins, Figs. 3b, c, 6, 9); or (ii) underwent only minor reactivation relative to the newly formed major faults during the main period of Late Jurassic rifting (e.g., Magnus sub-basin, Figs. 4a, h, 7, 8).

\section{Discussion}

6.1 Do pre-existing normal faults control rift geometry?

Physical models, and several field and subsurface-based studies, suggest that structures produced by an earlier phase of extension strongly control the pattern of faulting and rift geometry. In areas where dip angle, dip direction and stress conditions are favourable, earlier developed faults will be prone to reactivation (e.g., Keep and McClay, 1996; Morley et al., 2004; Bellahsen and 
Daniel, 2005; Henza et al., 2010 \& 2011; Whipp et al., 2014; Duffy et al., 2015). However, this relationship can be complex; for example, some or only parts of the earlier developed fault array may be reactivated (Lee and Hwang, 1993; Thomas and Coward, 1995; Tomasso et al., 2008), and/or fault reactivation may be strongly diachronous (e.g., Bell et al., 2014). Our study shows that many earlier developed faults in the East Shetland Basin were not reactivated, but cross-cut by newly formed, relatively steep-dipping faults, during subsequent extension (Figs. 4e, f, 5, 6-8), and thus played only a minor role in controlling the subsequent rift geometry. This directly challenges the view forwarded by most previous studies that do suggest key control of earlier developed faults on subsequent rift geometry (e.g., Badley et al., 1988; Coward 1990 \& 1993; Lee and Hwang, 1993; Rattey and Hayward, 1993; than to create new faults (e.g., Ranalli and Yin, 1990; Yin and Ranalli, 1992; several earlier developed faults as the result of burial, making the pre-existing faults less favourable for reactivation (e.g., Ranalli and Yin, 1990; Yin and

411 Ranalli, 1992; Morley, 1999). The results of our study are thus broadly

412 consistent with those of Tomasso et al. (2008), who argue that fault activity 
413 during a first rift phase (Triassic) was mostly focused on $\mathrm{N}$-trending, west-

414 dipping faults, which subsequently were cross-cut by $\mathrm{N}$-trending, east-dipping

415 faults during the a second rift phase (Middle-to-Late Jurassic). However, in

416 terms of timing, we found no convincing evidence for Triassic age, $\mathrm{N}$-trending,

417 west-dipping faults in the SE of the East Shetland Basin. Using our regional

418 dataset, we demonstrate that Triassic rifting did not occur in the east of the

419 East Shetland Basin. Our observations suggest Triassic development of a

420 single large $\mathrm{N}$-trending, west dipping fault on the western margin of the East

421 Shetland Basin. In the footwall of this large fault Triassic deposits gradually

422 thicken eastward, reflecting rift activity east of the East Shetland Basin, in the

423 North Viking Graben or on the Horda Platform (Figs. 3, 4d, 5-8).

424 Nevertheless, in the context of the influence of pre-existing normal faults, the

425 mechanical characteristics as a result of subsequent burial, compaction, and

426 associated rotation to lower dips are thus important, as these may make a

427 fault less favourable for reactivation. The impact of these mechanical

428 characteristics during rifting, however, are not typically directly incorporated in

429 physical models of multiphase rifting (e.g., Keep and McClay, 1996; Bellahsen

430 and Daniel, 2005; Henza et al., 2010, 2011; Agostini et al., 2011). This

431 modelling limitation is important, because it suggests such models potentially

432 overestimate the importance of fault reactivation during multiphase rifting.

4346.2 Does the lithosphere thermal and rheological state and structure influence

435 rift geometry? 
The recognition that reactivation of earlier developed faults was limited throughout the East Shetland Basin, indicates that the presence of preexisting faults is not always a major control on rift geometry development. Heterogeneity in the mechanical characteristics of earlier developed faults (see section 6.1), and moreover, the observed migration of strain throughout the development of the East Shetland Basin (see section 5) suggests that rift geometry is likely affected by processes other than crustal-scale heterogeneity. Lithosphere-scale numerical models suggest that the thermal evolution and structure of the asthenosphere and subcrustal lithosphere affects rift-related crustal deformation (e.g., Buck et al, 1999; Odinsen et al., 2000; Huismans et al., 2001; Behn et al., 2002; Cowie et al., 2005; Nagel and Buck, 2007). For example, using a finite element model Behn et al. (2002) predict that, when no regional temperature gradient is imposed on the part of the crust being stretched, deformation will be distributed between several conjugate fault systems forming a relatively wide rift. In contrast, in the presence of a horizontally varying temperature field, perhaps imposed by an earlier rift event, rift-related faulting focuses where the lithosphere is thinnest (Behn et al., 2002). Cowie et al. (2005) expand on this numerical model and link this prediction to the eastern part of the East Shetland Basin. They demonstrate a gradual change from distributed faulting to localised faulting on large, $\mathrm{N}$-trending, east-dipping faults, and finally to large-scale strain migration into the Viking Graben during Middle-Late Jurassic rifting (Fig. 1a). Based on numerical modelling, Cowie et al. (2005) suggest that the strain migration is a result of horizontal variations in the lithospheric temperature field. We observe a broadly similar style of large-scale strain migration throughout the entire 
East Shetland Basin (Fig. 10). However, Cowie et al. (2005) suggest that the strain migration occurs during the Middle Jurassic-to-earliest Cretaceous reactivating Permian-Triassic faults, while we show that, rather than two discrete phases of extension separated by a period of tectonic quiescence, the East Shetland Basin developed in response to a single, somewhat protracted phase of rifting ( $150 \mathrm{Myr})$ from pre-Triassic to Cretaceous with limited reactivation (Fig. 10). Nevertheless we draw a similar conclusion to Cowie et al., (2005), that the Middle-to-Late Jurassic geometry of the northern North Sea is strongly influenced by the evolving thermal structure of the lithosphere, leading to strain localization in the upper crust.

Although our study and that of Cowie et al. (2005) are limited to the western margin of the northern North Sea rift, our results support predictions of the tectonostratigraphic forward model of Odinsen et al. (2000). They suggest the thermal structure of the lithosphere across the whole northern North Sea rift reflects differences between the Permian-Triassic and Jurassic extension: a wide thermal perturbation during the Permian-Triassic, and a narrow thermal perturbation, focused under the North Viking Graben, during the Jurassic (Fig. 10). Moreover, our results are consistent with those of Bell et al. (2014), who show that faulting patterns on the Norwegian margin of the North Viking Graben are not solely controlled by reactivation of underlying, PermianTriassic faults. Bell et al. (2014), also speculate that the larger rift geometry 483 lithosphere and variations in the regional stress field.

Rifting is typically described using two end-members, where passive rifting is 485 driven by far-field extensional stresses and the space created by lithosphere 
thinning is passively filled by the atmosphere, and active rifting is driven by active mantle plume impingement on the base of the lithosphere (e.g., Huismans et al. 2001). However, multiple studies based on 2D plain-strain thermo-mechanical finite-element models, describe rift narrowing during symmetrical continental rifting, whereby a change from wide, passive extension to narrow, active extension might take place during the late syn-rift and or post-rift (e.g., Huismans et al., 2001; Huismans and Beaumont 2007; Nagel and Buck, 2007). Rift narrowing, thus, involves an evolving thermal and rheological lithosphere during rifting. We therefore argue that the pre-Triassic to Cretaceous eastward strain migration we document in the East Shetland Basin demonstrates a natural example of rift narrowing. Even though the time interval of the numerical models (e.g., 40 Myr full rift, Huismans et al., 2001) is smaller than the northern North Sea rift phase ( 150 Myr failed rift, Færseth, 1996), the results of Huismans et al. (2001), Huismans and Beaumont (2007), and Nagel and Buck (2007), arguably demonstrate a progressive change from a wide to narrower rift, as observed by previous studies (e.g., Færseth, 1996; Odinsen et al., 2000; Cowie et al., 2005; Bell et al., 2014) and our study (Figs. $4,10)$. We draw on the predictions of the previous numerical models to suggest that in the northern North Sea the observed gradual change in rift style from wide to narrow is more likely to be the result of the lithospheric thermal and rheological evolution prior to the Late Jurassic rift maximum phase, rather than the interaction of pre-Jurassic and Jurassic rift structures as suggested by previous work (e.g., Badley et al., 1988; Coward, 1993; Færseth, 1996). We interpret that narrowing of the rift is associated with the evolving thermal and rheological structure of the lithosphere. Although pre- 
existing structures are able to influence subsequent rift-related structures, the

512 larger lithosphere-scale thermal and rheologic heterogeneity may serve to

513 dilute their control on rift geometry.

\section{Conclusion}

516 Our observations in the East Shetland Basin, northern North Sea,

517 demonstrate that pre-existing rift related faults may have a much more limited 518 control on rift geometry and evolution in multiphase rifts than previously 519 believed. Using a regional, high quality, subsurface dataset, we document 520 how only few pre-existing faults reactivate, while most are buried and/or

521 cross-cut by younger rift-related faults during a protracted, pre-Triassic to

522 Cretaceous rift phase. We argue that limited reactivation may reflect fault

523 strengthening and/or fault dip rotation due to the burial and compaction.

524 Moreover, we suggest that the upper crustal strain migration and rift

525 narrowing is a result of the evolving lithosphere, which is in accordance with 526 predictions of lithosphere-scale numerical models of continental break-up and 527 rifting. Although the control of pre-existing faults is clearly observed in natural 528 examples on the scale of a fault system (e.g., Whipp et al., 2014; Duffy et al., 529 2015), we propose that on a rift scale this influence might be overestimated 530 and less important than lithosphere-scale variations thermal and rheological 531 characteristics as predicted by lithosphere-scale numerical models (e.g., 532 Huismans et al., 2001; Huismans and Beaumont 2007; Nagel and Buck, 533 2007). We, therefore, caution against the application of predictions from 
analogue models, which do not include the role of lithospheric thermal and rheological evolution.

\section{Acknowledgements}

This work is funded by a Statoil Departmental Scholarship at Imperial College

539 London and the MultiRift Project, which is funded by the Research Council of

540 Norway (PETROMAKS Project number 215591/E30) and Statoil to the

541 University of Bergen, and partners Imperial College London, University of

542 Manchester and University of Oslo. We thank editor Rebecca Bendick, and

543 two anonymous reviewers for their constructive reviews Al Fraser and Jon

544 Bull are thanked for their comments on earlier versions of this manuscript. For

545 their involvement in providing the subsurface data and the permission to

546 publish, we are grateful to Thomas Weight, Tom Dreyer, Mark Lawson, Claire

547 Thomas, and Bart Hendriks at Statoil, Richard Lamb at PGS, and Bent

548 Kjølhamar at TGS. Schlumberger is thanked for providing Petrel to Imperial

549 College. We thank the members of the Basins Research Group at Imperial

550 College London and the MultiRift Project, especially Thilo Wrona, for useful 551 discussion.

\section{References}

Agostini, A., Bonini, M., Corti, G., Sani, F., \& Mazzarini, F., 2011, Fault architecture in the Main Ethiopian Rift and comparison with experimental models: Implications for rift evolution and Nubia-Somalia kinematics, Earth and Planetary Science Letters, 301, 479-492. http://dx.doi.org/10.1016/j.epsl.2010.11.024 
Badley, M. E., Price, J. D., Rambech Dahl, C., and Agdestein, T., 1988, The structural evolution of the northern Viking Graben and its bearing upon extensional modes of basin formation, J. Geol. Soc., 145, 455-472. http://dx.doi.org/10.1144/gsjgs.145.3.0455

Behn, M. D., Lin, J. and Zuber, M. T., 2002, A continuum mechanics model for normal faulting using a strain-rate softening rheology: implications for thermal and rheological controls on continental and oceanic rifting, Earth and Planetary Science Letters, 202, 725-740. http://dx.doi.org/10.1016/S0012-821X(02)00792-6

Bell, R. E., Jackson, C. A-L., Whipp, P. S., and Clements, B., 2014, Strain migration during multiphase extension: Observations from the northern North Sea, Tectonics, 33, 1936-1963. http://dx.doi.org/10.1002/2014TC003551

Bellahsen, N., and Daniel, J. M., 2005, Fault reactivation control on normal fault growth: an experimental study, Journal of Structural Geology, 27, 769-780. http://dx.doi.org/10.1016/j.jsg.2004.12.003

Buck, W. R., Lavier, L. L., and Poliakov, A. N. B., 1999, How to make a rift wide, Philosophical Transactions of the Royal Society of London, Series A: Mathematical, Physical and Engineering Sciences, 357, 671-693. https://doi.org/10.1098/rsta.1999.0348

Childs, C., A. Nicol, J. J. Walsh, and J. Watterson, 2003, The growth and propagation of synsedimentary faults, J. Struct. Geol., 25, 633-648. http://dx.doi.org/10.1016/S0191-8141(02)00054-8

Coward, M. P., 1990, The Precambrian, Caledonian and Variscan framework to NW Europe, Geological Society, London, Special Publications, 55, 134. http://dx.doi.org/10.1144/GSL.SP.1990.055.01.01

Coward, M. P., 1993, The effect of Late Caledonian and Variscan continental escape tectonics on basement structure, Paleozoic basin kinematics and subsequent Mesozoic basin development in NW Europe. In: Geological Society, London, Petroleum Geology Conference series, Geological Society of London, 1095-1108. http://dx.doi.org/10.1144/0041095

Cowie, P. A., Underhill, J. R., Behn, M. D., Lin, J., and Gill, C. E., 2005, Spatio-temporal evolution of strain accumulation derived from multiscale observations of Late Jurassic rifting in the northern North Sea: $A$ critical test of models for lithospheric extension, Earth and Planetary Science Letters, 234, 401-419. http://dx.doi.org/10.1016/j.epsl.2005.01.039

Doré, A.G., Lundin, E.R., Fichler, C. and Olesen, O., 1997, Patterns of basement structure and reactivation along the NE Atlantic margin, Journal of the Geological Society, 154, pp.85-92. http://dx.doi.org/10.1144/gsjgs.154.1.0085

Duffy, O.B., Bell, R.E., Jackson, C.A., Gawthorpe, R.L. and Whipp, P.S., 2015, Fault growth and interactions in a multiphase rift fault network: 
Horda Platform, Norwegian North Sea, Journal of Structural Geology, 80, pp.99-119. http://dx.doi.org/10.1016/j.jsg.2015.08.015

Faccenna, C., Nalpas, T., Brun, J.P., Davy, P. and Bosi, V., 1995, The influence of pre-existing thrust faults on normal fault geometry in nature and in experiments. Journal of Structural Geology, 17, pp.1139-1149. http://dx.doi.org/10.1016/0191-8141(95)00008-2

Færseth, R. B., 1996, Interaction of Permo-Triassic and Jurassic extensional fault-blocks during the development of the northern North Sea, Journal of the Geological Society, 153, 931-944. http://dx.doi.org/10.1144/gsjgs.153.6.0931

Gawthorpe, R.L., Jackson, C.A.L., Young, M.J., Sharp, I.R., Moustafa, A.R. and Leppard, C.W., 2003, Normal fault growth, displacement localisation and the evolution of normal fault populations: the Hammam Faraun fault block, Suez rift, Egypt, Journal of Structural Geology, 25, pp.883-895. http://dx.doi.org/10.1016/S0191-8141(03)00059-2

Henza, A. A., Withjack, M. O., and Schlische, R. W., 2010, Normal-fault development during two phases of non-coaxial extension: An experimental study, Journal of Structural Geology, 32, 1656-1667. http://dx.doi.org/10.1016/j.jsg.2009.07.007

Henza, A. A., Withjack, M. O., and Schlische, R. W., 2011, How do the properties of a pre-existing normal-fault population influence fault development during a subsequent phase of extension?, Journal of Structural Geology, 33, 1312-1324. http://dx.doi.org/10.1016/j.jsg.2011.06.010

Huismans, R. S., Podladchikov, Y. Y. and Cloetingh, S. A. P. L., 2001, The transition from passive to active rifting, relative importance of asthenospheric doming and passive extension of the lithosphere, Journal of Geophysical Research, 106, 11,271-11,291. http://dx.doi.org/10.1029/2000JB900424

Huismans, R. S., Beaumont, C. 2007, Roles of lithospheric strain softening and heterogeneity in determining the geometry of rifts and continental margins, Geol. Soc. London Spec. Publ., 282, 111-138. http://dx.doi.org/10.1144/SP282.6

Keep, M., and McClay, K.R., 1997, Analogue modelling of multiphase rift systems, Tectonophysics, 273, 239-270. http://dx.doi.org/10.1016/S0040-1951(96)00272-7

Lavier, L. L., \& Manatschal, G., 2006, A mechanism to thin the continental lithosphere at magma-poor margins, Nature, 440(7082), 324-328. http://dx.doi.org/10.1038/nature04608

Lee, M. J., and Hwang, Y. J., 1993, Tectonic evolution and structural styles of the East Shetland Basin. Geological Society of London, Petroleum Geology Conference series, 4, 1137-1149. http://dx.doi.org/10.1144/0041137 
McLeod, A. E., Dawers, N. H., and Underhill, J. R., 2000, The propagation and linkage of normal faults: Insights from the Strathspey-BrentStatfjord fault array, northern North Sea, Basin Research, 12, 263-284. http://dx.doi.org/10.1111/j.1365-2117.2000.00124.x

Morley, C.K., 1999. How successful are analogue models in addressing the influence of pre-existing fabrics on rift structure?, Journal of Structural Geology, 21, pp.1267-1274. http://dx.doi.org/10.1016/S01918141(99)00075-9

Morley, C. K., Haranya, C., Phoosongsee, W., Pongwapee, S., Kornsawan, A., and Wonganan, N., 2004, Activation of rift oblique and rift parallel pre-existing fabrics during extension and their effect on deformation style: examples from the rifts of Thailand, Journal of Structural Geology, 26, 1803-1829. http://dx.doi.org/10.1016/j.jsg.2004.02.014

Nagel, T.J., and Buck, W.R., 2007, Control of rheological stratification on rifting geometry: a symmetric model resolving the upper plate paradox, International Journal of Earth Science, 96, 1047-1057. http://dx.doi.org/10.1007/s00531-007-0195-x

Naliboff, J., and Buiter, S.J.H., 2015, Rift reactivation and migration during multiphase extension, Earth and Planetary Science Letters, 421, 58-67. http://dx.doi.org/10.1016/j.epsl.2015.03.050

Nixon, C. W., Bull, J. M., \& Sanderson, D. J., 2014, Localized vs distributed deformation associated with the linkage history of an active normal fault, Whakatane Graben, New Zealand, Journal of Structural Geology, 69, 266-280. http://dx.doi.org/10.1016/j.jsg.2014.06.005

Odinsen, T., Reemst, P., Van der Beek, P., Faleide, J. I., and Gabrielsen, R. H., 2000, Permo-Triassic and Jurassic extension in the northern North Sea: results from tectonostratigraphic forward modelling, Dynamics of the Norwegian Margin, Geological Society, London, Special Publications 167, 83-103. http://dx.doi.org/10.1144/GSL.SP.2000.167.01.05

Phillips, T.B., Jackson, C.A., Bell, R.E., Duffy, O.B. and Fossen, H., 2016, Reactivation of intrabasement structures during rifting: A case study from offshore southern Norway, Journal of Structural Geology, 91, pp. 54-73. http://dx.doi.org/10.1016/j.jsg.2016.08.008

Platt, N. H. 1995, Structure and tectonics of the northern North Sea: new insights from deep penetration regional seismic data, Geological Society, London, Special Publications, 80, 103-113. http://dx.doi.org/10.1144/GSL.SP.1995.080.01.05

Ranalli, G., Yin, Z.M., 1990, Critical stress difference and orientation of faults in rocks with strength anisotropies: the two-dimensional case, Journal of Structural Geology 12, 1067-1071. http://dx.doi.org/10.1016/01918141(90)90102-5 
Rattey, R. P., and Hayward, A. B., 1993, Sequence stratigraphy of a failed rift system: the Middle Jurassic reservoir distribution within the UK central North Sea, In: R. J. Parker (Ed.), Petroleum geology of northwest Europe: London, Geological Society, 215-250. http://dx.doi.org/10.1144/0040215

Reeve, M. T., Bell, R. E., and Jackson, C. A-L., 2013, Origin and significance of intra-basement reflections offshore western Norway, J. Geol. Soc., 171, 1-4. http://dx.doi.org/10.1144/jgs2013-020

Reston, T. J., 2005, Polyphase faulting during the development of the west Galicia rifted margin, Earth and Planetary Science Letters, 237, 561576. http://dx.doi.org/10.1016/j.epsl.2005.06.019

Roberts, A. M., Yielding, G., Kusznir, N. J., Walker, I. M., \& Dorn-Lopez, D., 1995, Quantitative analysis of Triassic extension in the northern Viking Graben, Journal of the Geological Society, 152, 15-26. http://dx.doi.org/10.1144/gsjgs.152.1.0015

Sibson, R.H., 1985, A note on fault reactivation, Journal of Structural Geology, 7, pp.751-754. http://dx.doi.org/10.1016/0191-8141(85)90150-6

Strecker, M. R., Blisniuk, P. M., and Eisbacher, G. H., 1990, Rotation of extension direction in the central Kenya Rift, Geology, 18, 299-302. http://dx.doi.org/10.1130/0091-7613(1990)018<0299:ROEDIT>2.3.CO;2

Tenthorey, E. and Cox, S.F., 2006, Cohesive strengthening of fault zones during the interseismic period: An experimental study, Journal of Geophysical Research: Solid Earth, 111(B9). http://dx.doi.org/10.1029/2005JB004122

Thomas, D. W., and Coward, M.P, 1995, Late Jurassic-Early Cretaceous inversion of the northern East Shetland Basin, northern North Sea, Geological Society, London, Special Publications, 88, 275-306. http://dx.doi.org/10.1144/GSL.SP.1995.088.01.16

Tomasso, M., Underhill, J. R., Hodgkinson, R. A., and Young, M. J., 2008, Structural styles and depositional architecture in the Triassic of the Ninian and Alwyn North fields: Implications for basin development and prospectivity in the Northern North Sea, Marine and Petroleum Geology, 25, 7, 588-605. http://dx.doi.org/10.1016/j.marpetgeo.2007.11.007

Whipp, P. S., Jackson, C., Gawthorpe, R. L., Dreyer, T., and Quinn, D., 2014, Normal fault array evolution above a reactivated rift fabric; a subsurface example from the northern Horda Platform, Norwegian North Sea, Basin Research, 26, 523-549. http://dx.doi.org/10.1111/bre.12050

Yin, Z.M., Ranalli, G., 1992, Critical stress difference, fault orientation and slip direction in anisotropic rocks under non-Andersonian stress systems, Journal of Structural Geology 14, 237-244. http://dx.doi.org/10.1016/0191-8141(92)90060-A 
728

729

730

731

732

Ziegler, P. A., and Cloetingh, S., 2004, Dynamic processes controlling evolution of rifted basins, Earth Sci. Rev., 64, 1-50. http://dx.doi.org/10.1016/S0012-8252(03)00041-2 


\section{Figure captions}

Figure 1: a) Major tectonic elements of the northern North Sea (after Færseth, 1996; Bell et al., 2014). b) Outlines of dataset used for this study. All wells are tied to the seismic data and contain stratigraphic data for the Jurassic (blue), Jurassic and Top Triassic (purple), and Jurassic and Triassic (red). c) Time-structure map of the Top Lunde Formation with major structural elements and faults: Alw = Alwyn Fault, Bre $=$ Brent Fault, Cor $=$ Cormorant Fault, Eid $=$ Eider Fault, ESP $=$ East Shetland Platform, Hea $=$ Heather Fault, Hud $=$ Hudson Fault, Hut $=$ Hutton Fault, MSB = Magnus sub-basin, Mur = Murchison Fault, Nin = Ninian, NSB = Ninian sub-basin, Osp = Osprey Fault, Pel $=$ Pelican Fault, Sta $=$ Statfjord Fault, Str $=$ Strathspey, TER $=$ Tern-Eider Ridge, Ter $=$ Tern Fault, TSB $=$ Tern sub-basin, Thi $=$ Thistle Fault, Tor $=$ Tordis Fault, W-M = West Margin Fault. The faults and structural features are named after the adjacent hydro-carbon bearing fields.

Figure 2: Stratigraphic column of the East Shetland Basin (modified after Fæseth, 1996). Showing the interpreted horizons and synthetic well ties Proposed sequence stratigraphy is based on Rattey and Hayward (1993). See Figure 5.1 for well locations. Depth $=$ TVD, GR = Gamma Ray, RHOB = Density, DT = Sonic, RC = Reflection Coefficient, AI = Acoustic Impedance.

Figure 3: Three interpreted 2D Time-migrated seismic reflection profiles crossing the study area in the a) north, b) centre, and c) south. The seismic profiles including well penetrations and major faults and structural features. See Figures $1 \mathrm{~b}$ for locations.

Figure 4: Isochrons overlain by fault polygons that offset the top surface (left) with line drawing of faults over outline of 3D seismic data coverage (grey polygons) (right) of a) Unit 1, b) Unit 2, c) Teist Formation, d) Lomvi and Lunde formations, e) Statford Formation, f) Dunlin Group, g) Brent Group h) Viking Group. Colours are based on the maximum and minimum thickness value in ms TWT per isochron. Contour interval on all the isochrons is $100 \mathrm{~ms}$ TWT. Hatched areas show locations where the top horizon is eroded. See caption of Figure 1 for abbreviated fault and structural features names. See Figure 1c for location.

Figure 5: Seismic section crossing the west-dipping Eider Fault, showing periods of fault growth. For location see Figure 1c, and for horizon abbreviations see Figure 3.

Figure 6: a) Seismic section crossing the Ninian sub-basin and the reactivated Ninian Fault showing an example of the burial of older structures. 
b) Seismic section crossing the Ninian sub-basin and reactivated Ninian Fault showing an older fault cross-cut by a younger fault. Growth periods are marked by white lines, and the eastward Triassic thickening direction is marked by the white dashed arrows. For location see Figure 1c, and for horizon abbreviations see Figure 3.

Figure 7: Seismic section crossing the Cormorant and Hutton faults showing an older fault cross-cut by a younger fault and burial of older structures. Growth periods are marked by white lines, and the eastward Triassic thickening direction is marked by the white dashed arrows. For location see Figure 1c, and for horizon abbreviations see Figure 3.

Figure 8: Seismic section crossing the Osprey and Hutton faults showing an older fault cross-cut by a younger fault. Growth periods are marked by white lines. For location see Figure 1c, and for horizon abbreviations see Figure 3.

Figure 9: Schematic block diagrams showing the evolution of the East Shetland Basin. From Pre-Triassic to Middle Triassic, strain is distributed across the whole basin (a-c). During the Middle-to-Late Triassic, strain is focussed on the western part of the basin (d). Strain switches to the eastern part of the basin during Latest Triassic-to-Middle Jurassic (e). Strain remains focussed on the eastern part of the basin throughout the Jurassic ( $f-h)$ Faults are coloured according to subsequent development of the basin.

Figure 10: Diagram showing the crustal evolution of the East Shetland Basin (colour) and the proposed evolution of the underlying lithosphere across the northern North Sea (grey scale) showing the transition from wide to narrow rifting (modified after Nagel and Buck, 1997). Strain migration through the East Shetland Basin is marked by the grey scale above the coloured zoom-ins per stage: darker grey indicates the location of relative high strain. a) Wide rift with strain distributed across the whole northern North Sea leading to faulting throughout the entire East Shetland Basin. b) Wide rift with possible focus below the Horda Platform. In the East Shetland Basin, strain is concentrated in the western part, reactivating the Eider Fault, while deposits in its footwall are thickening towards the east. c) Rifting is narrowing with its rift axis below the Viking Graben east of the East Shetland Basin. Strain switches to the eastern part of the East Shetland Basin where new faults initiate and some older faults reactivate near the rift axis. d) Rift maximum stage during narrow rifting with rift axis below the Viking Graben. In the East Shetland Basin, strain is increasing towards the eastern part, faults are reactivating, while new fault are initiating, sometimes burying or cross-cutting older pre-existing normal faults. 
Fiaure $1 \quad 0^{\circ}$

$2^{\circ} 00^{\prime} \mathrm{E}$

$4^{\circ} 00^{\prime} \mathrm{E}$

$6^{\circ} 00^{\prime} \mathrm{E}$
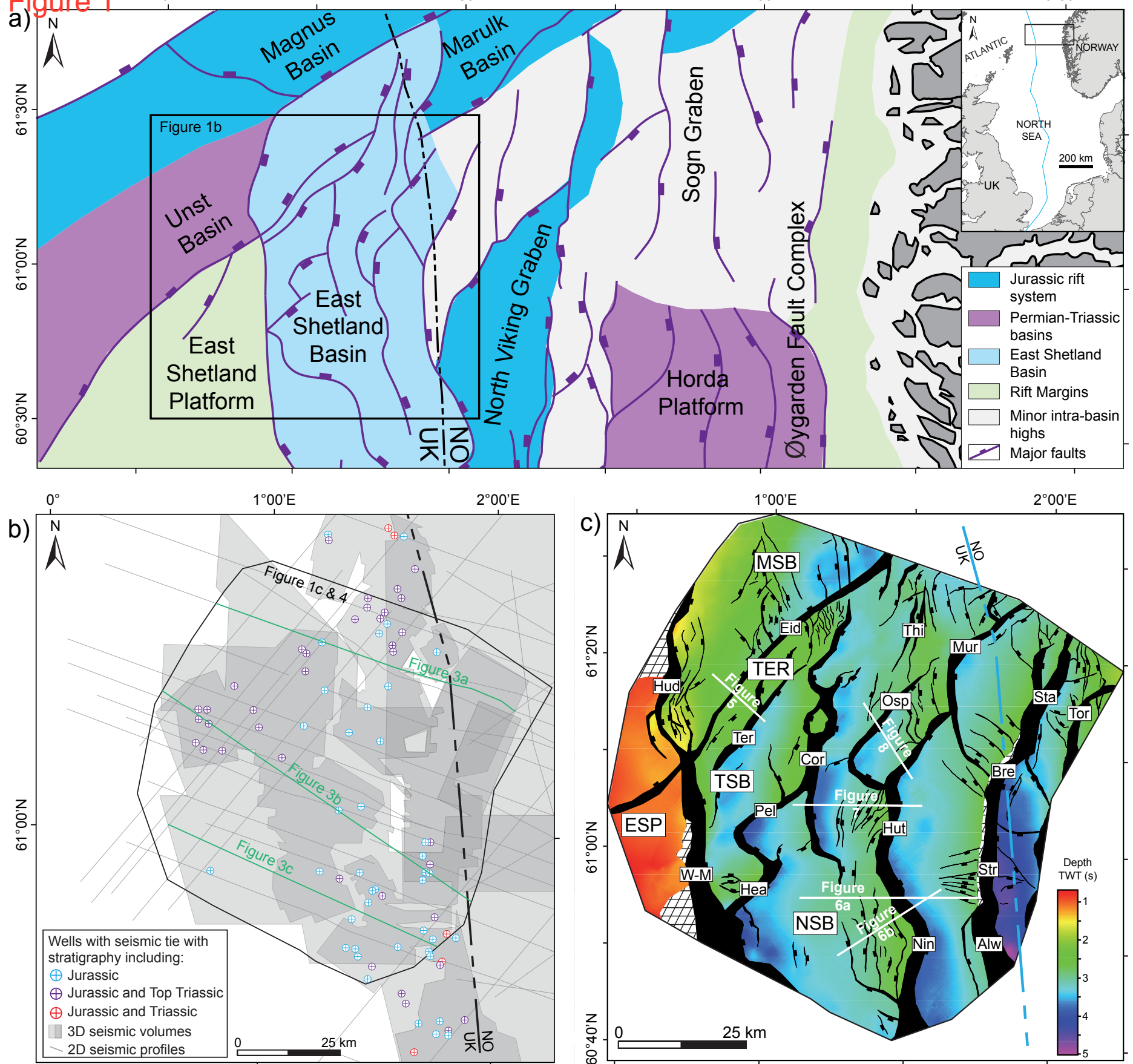


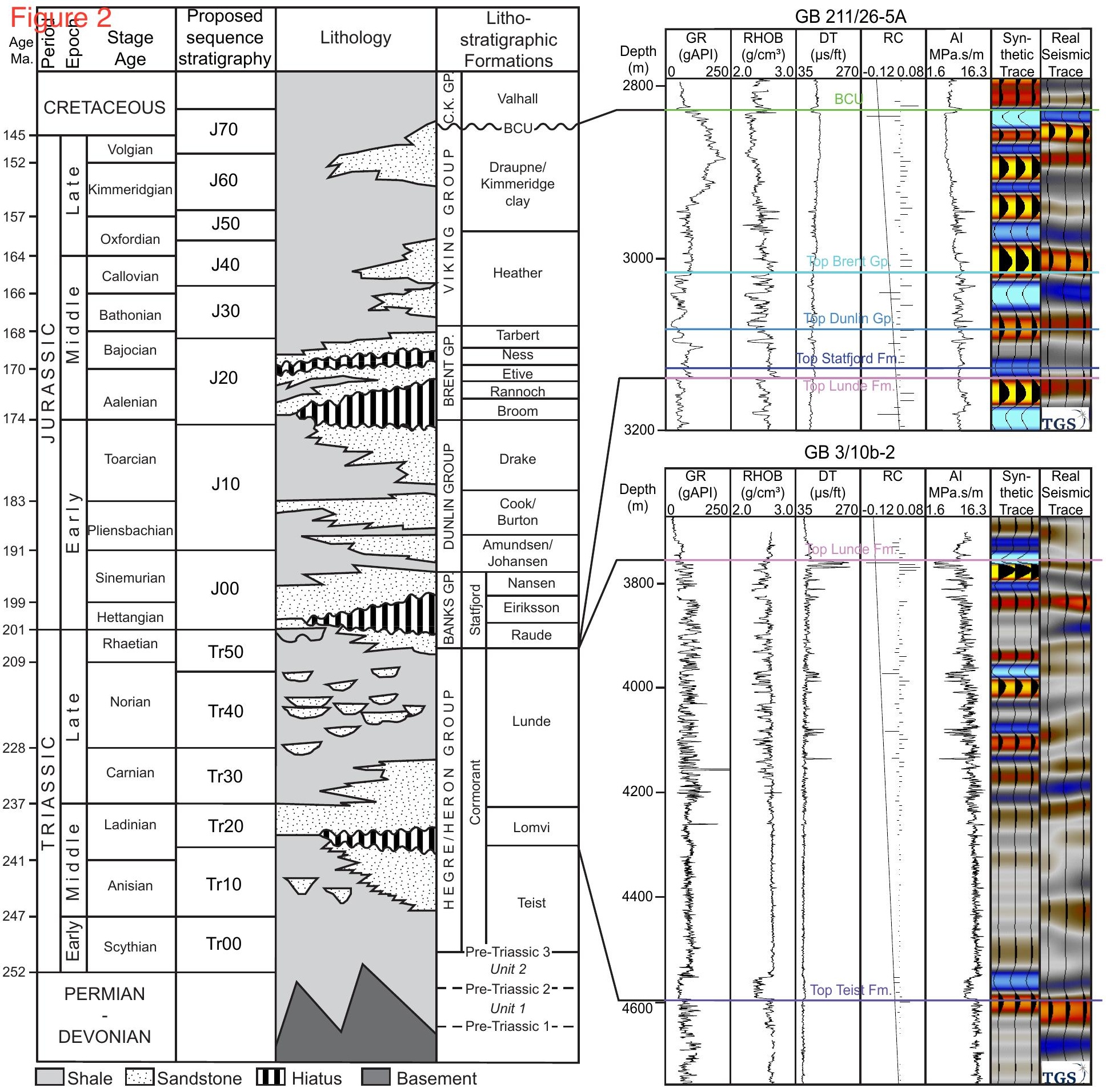




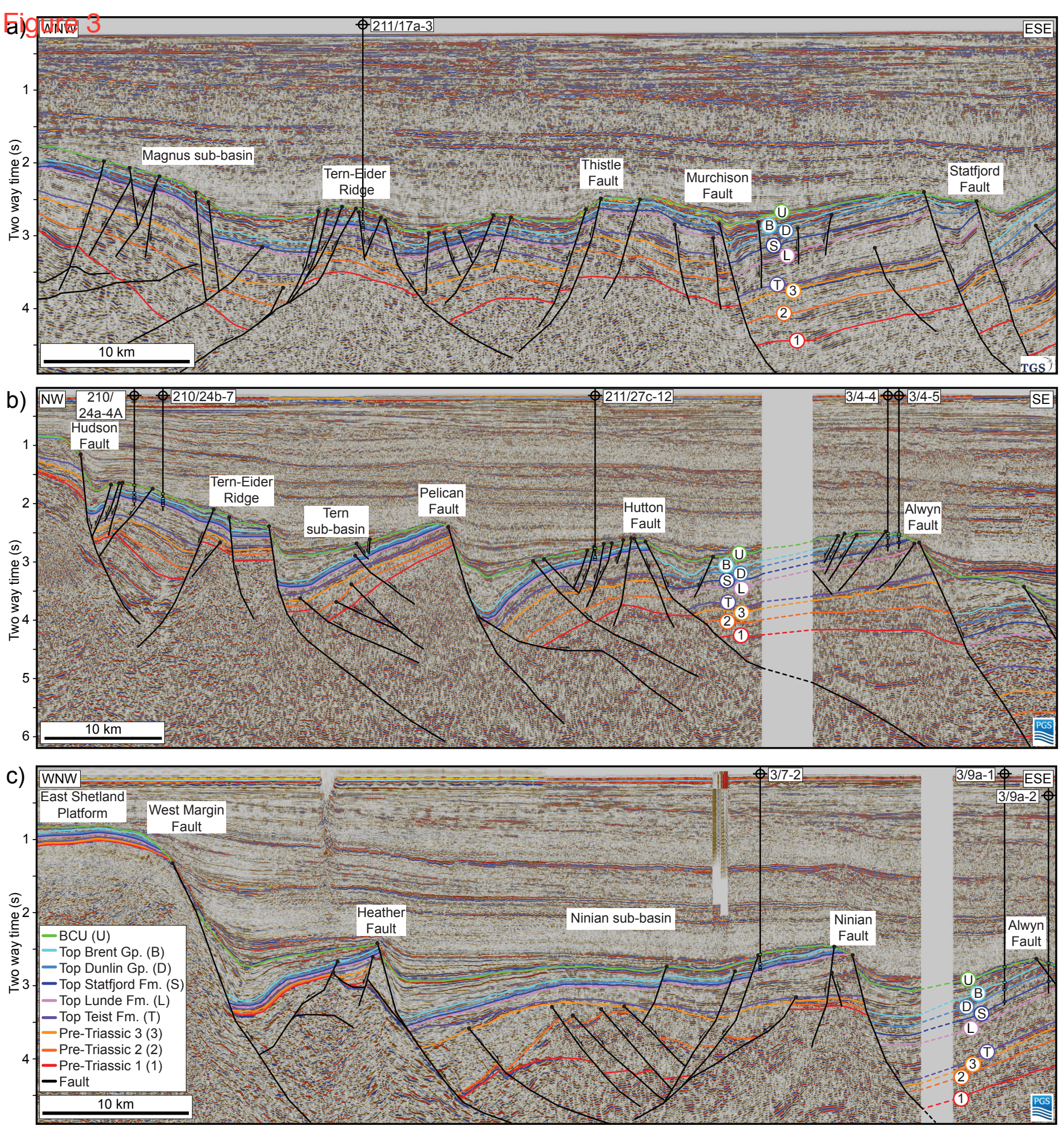


a) Unit 1 (Pre-Triassic 2 - Pre-Triassic 1)

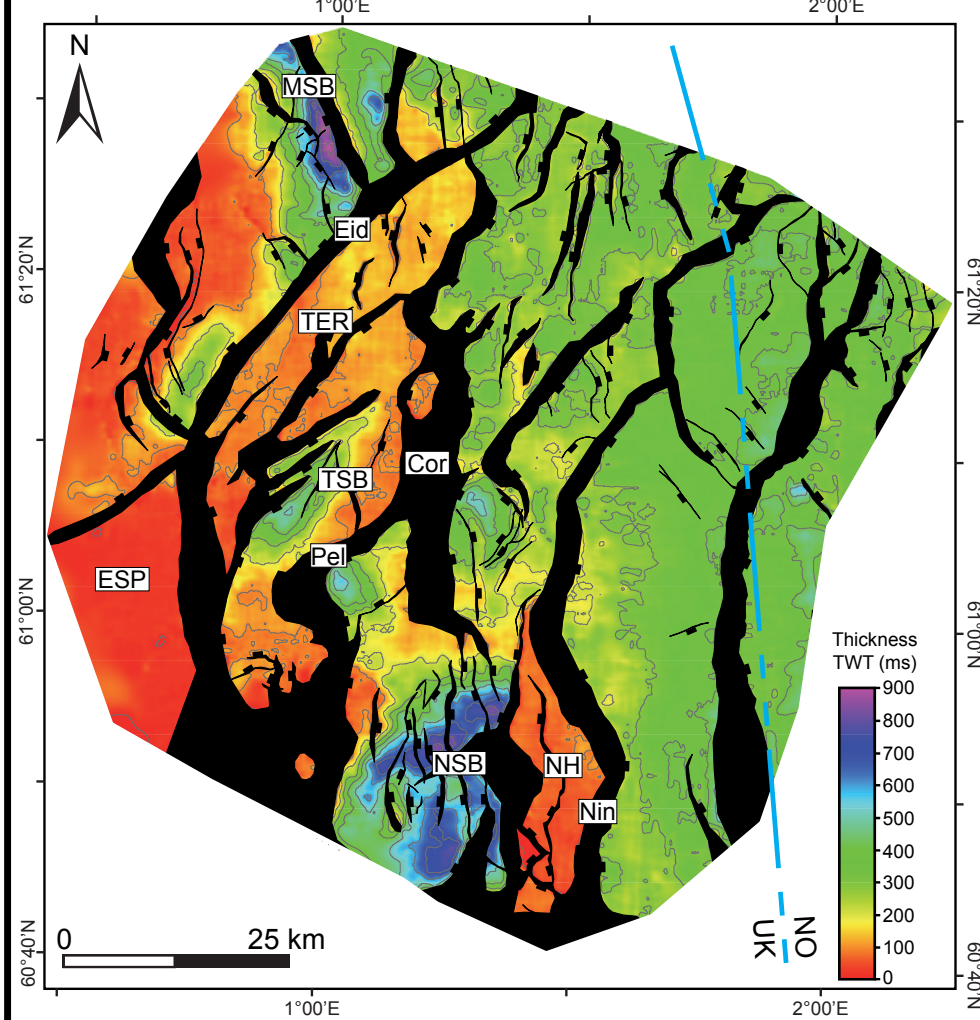

Figure 4

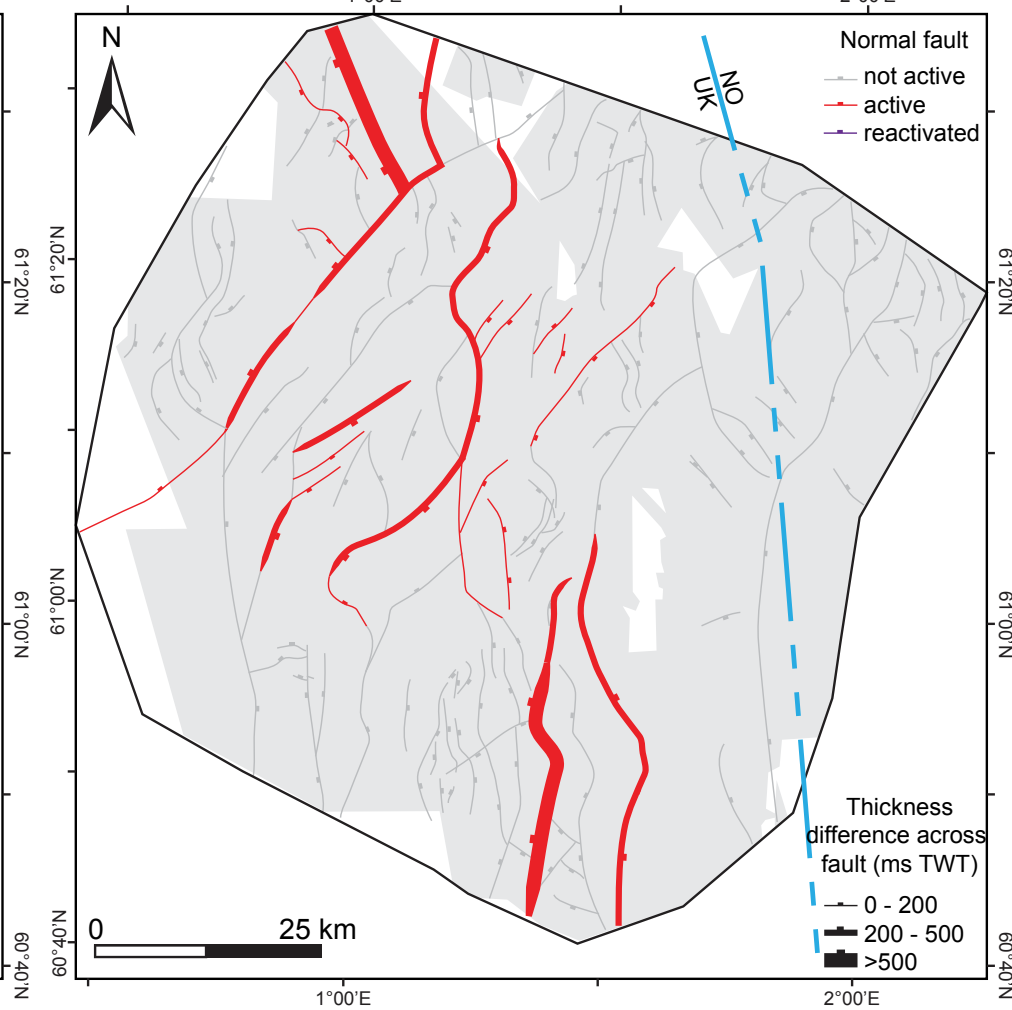

b) Unit 2 (Pre-Triassic 3 - Pre-Triassic 2)
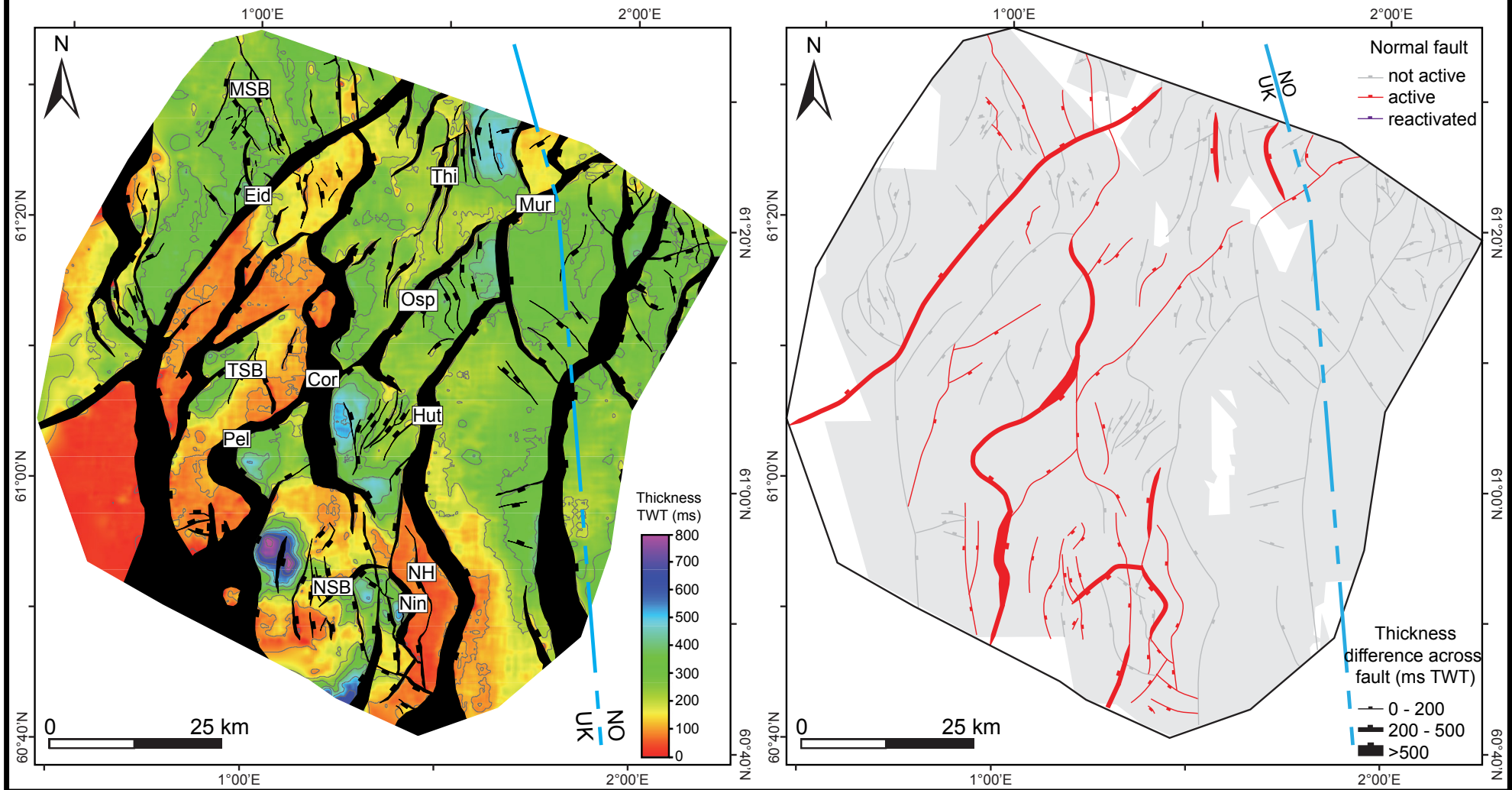

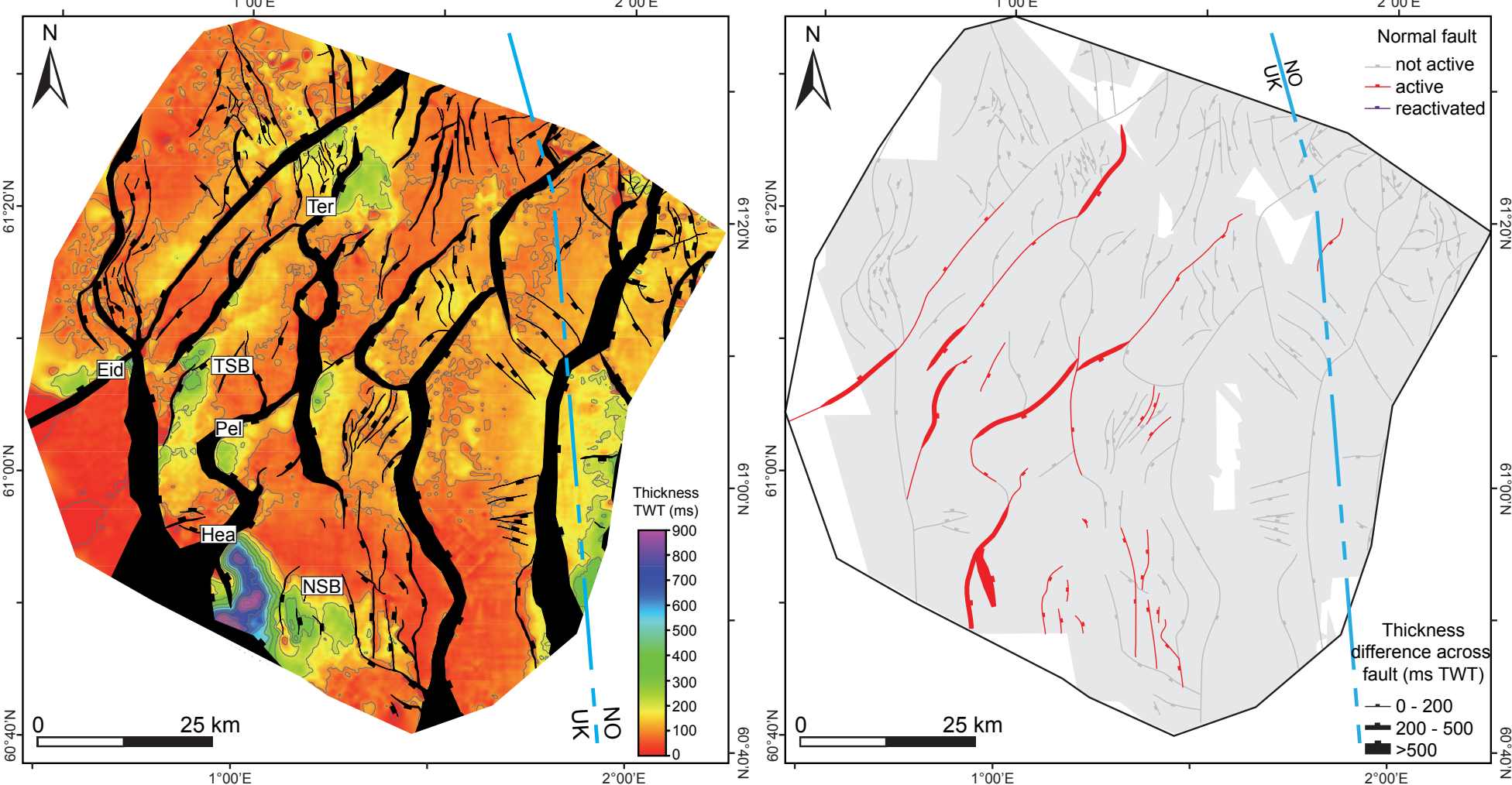

d) Lomvi and Lunde formations (Middle-to-Late Triassic)
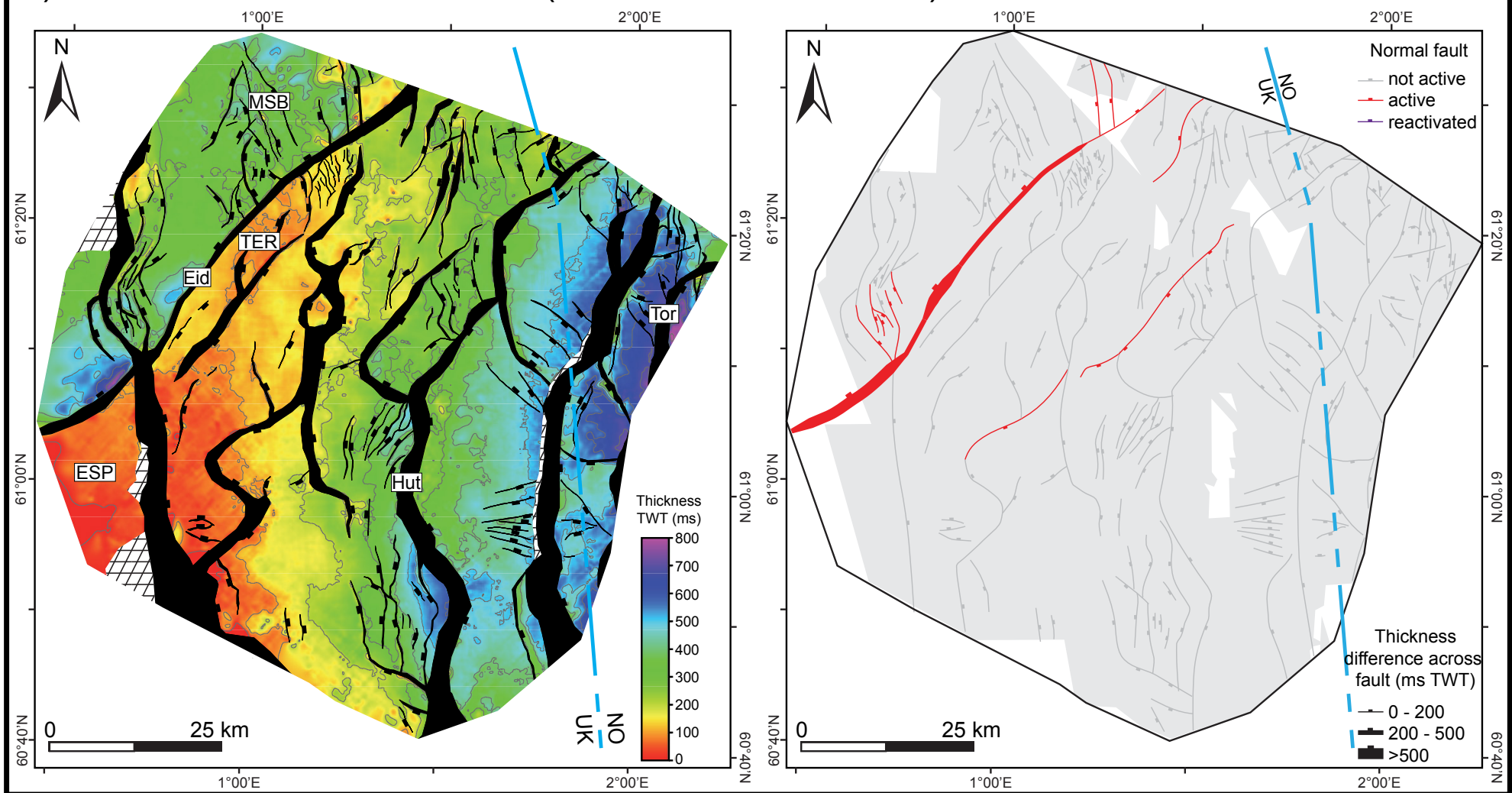

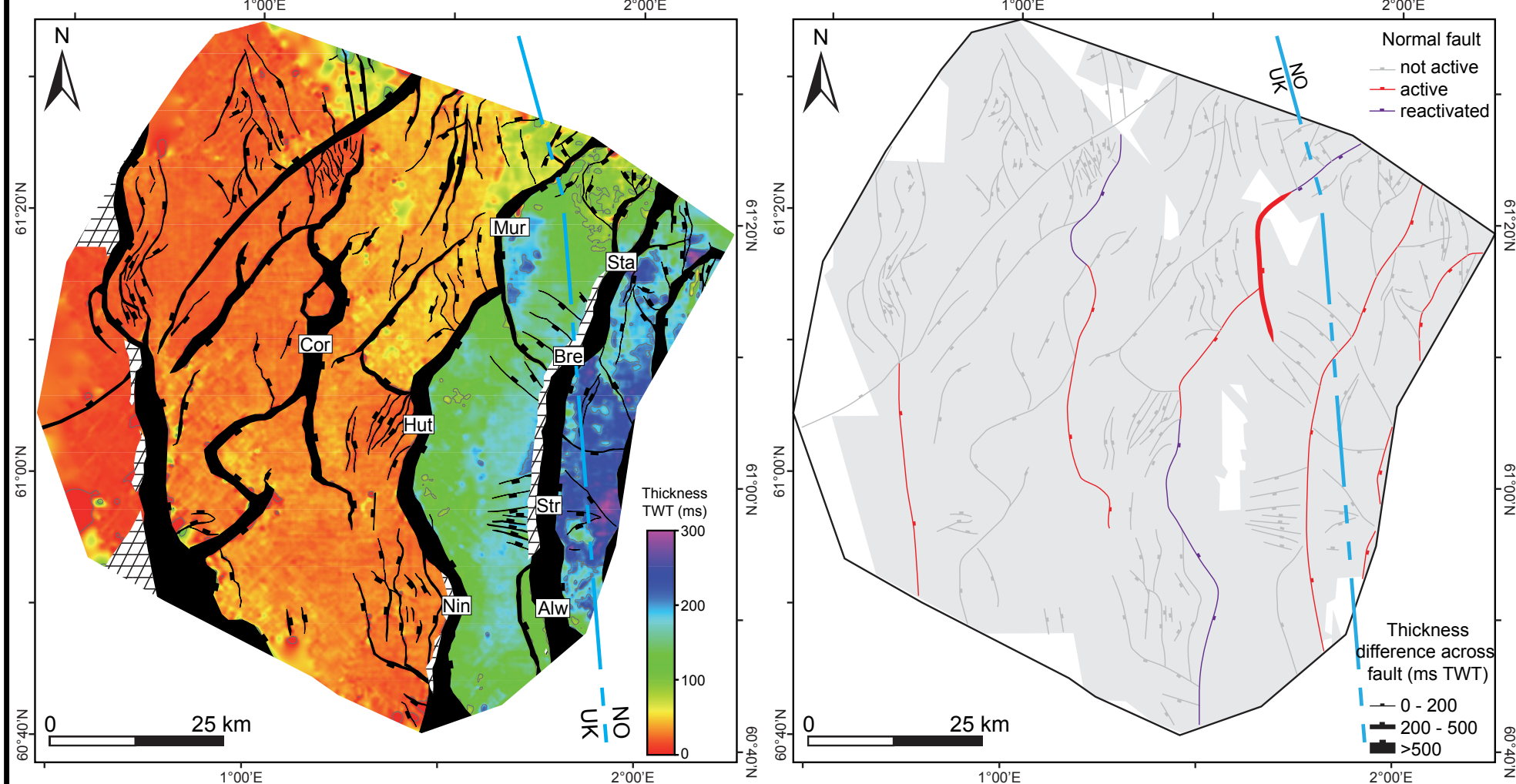

f) Dunlin Group (Early Jurassic)
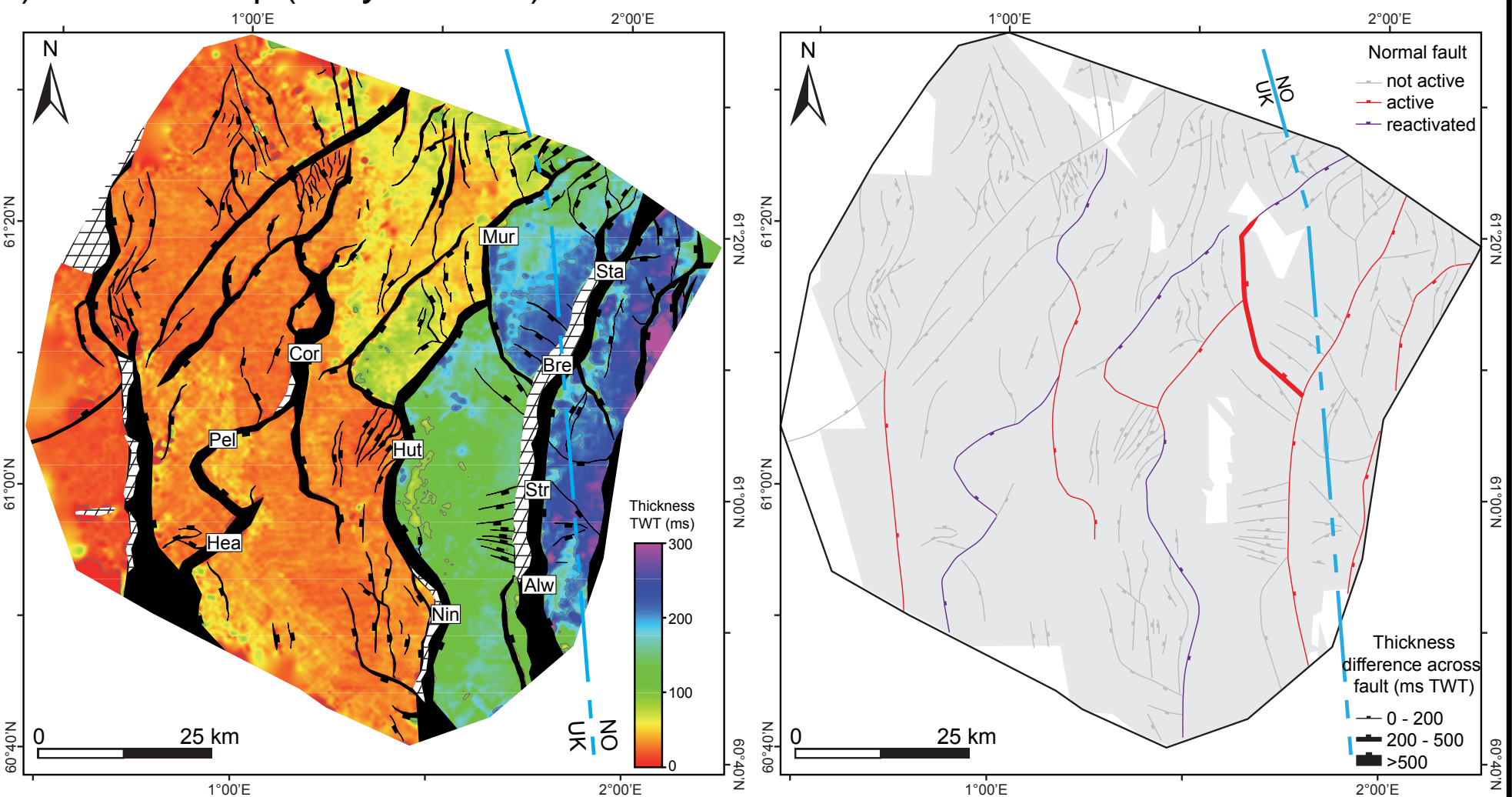
g) Brent Group (Middle Jurassic)

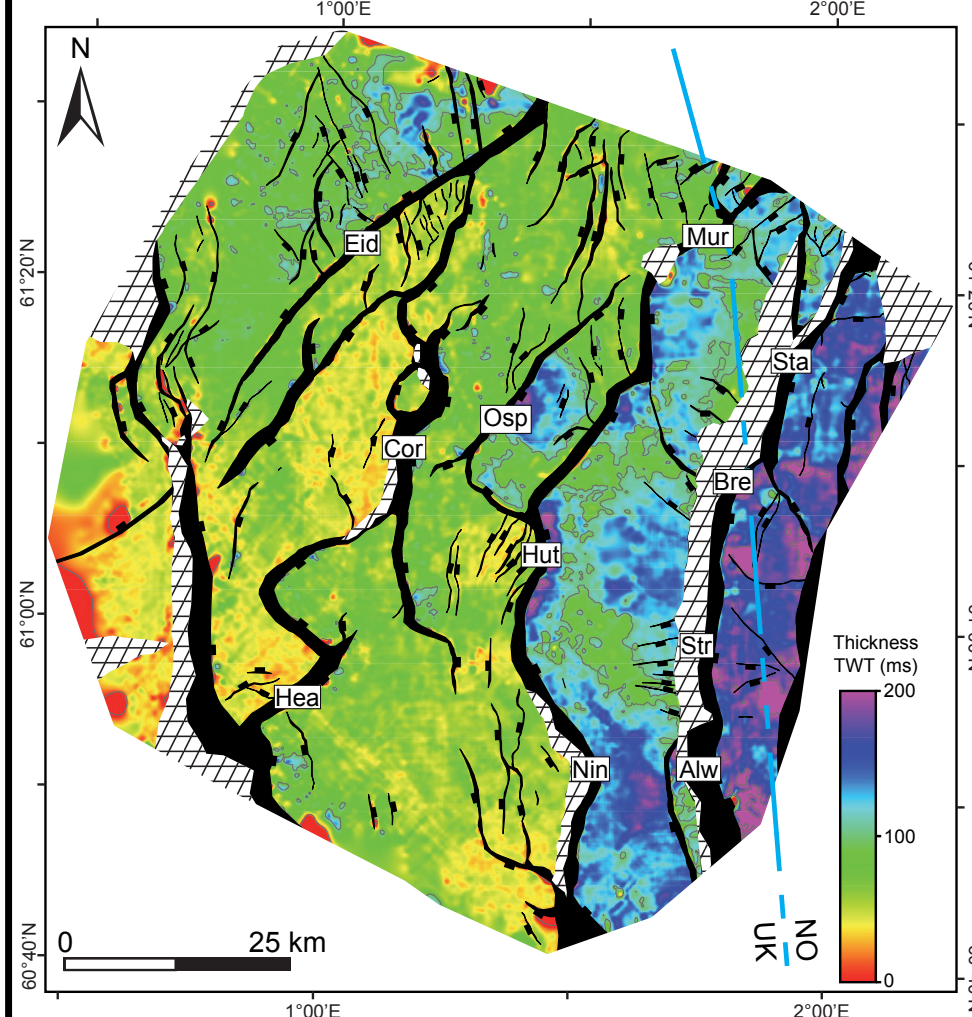

Figure 4 ${ }^{20} \mathrm{NO}^{2}$

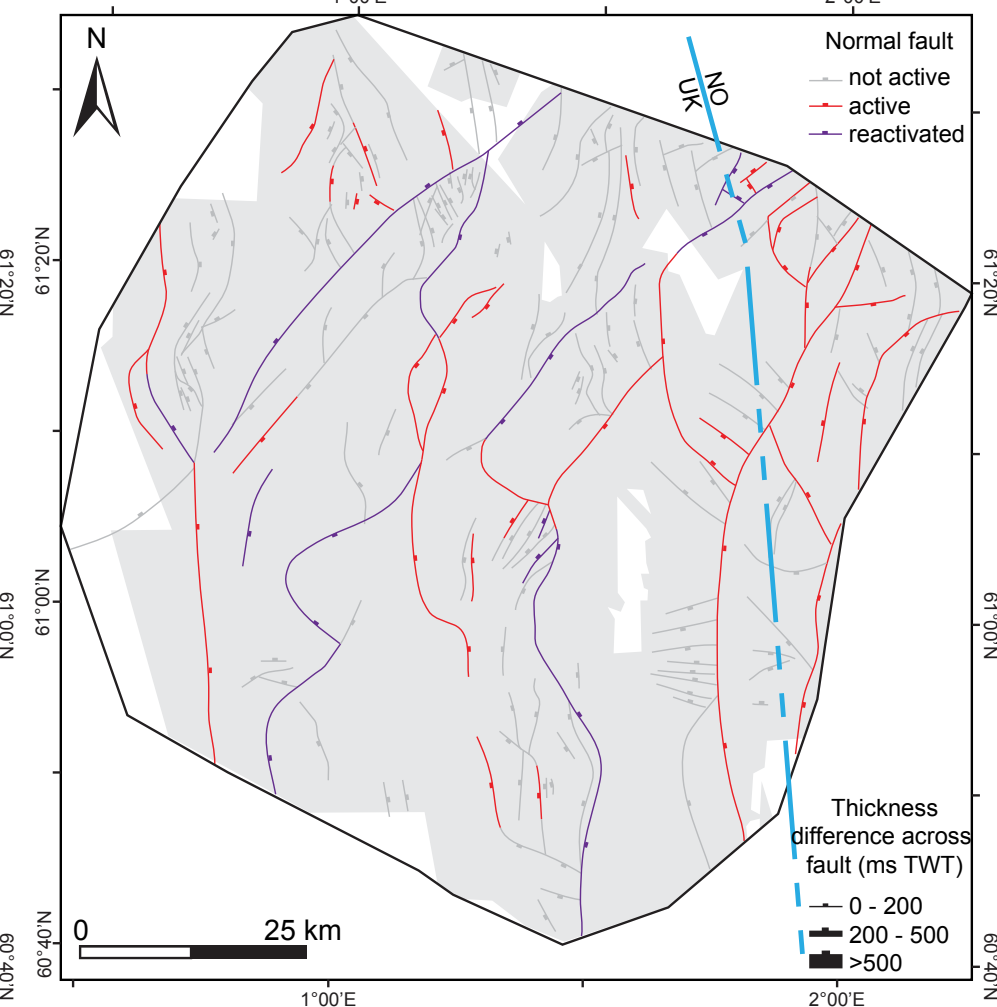

h) Viking Group (Middle-to-Late Jurassic)
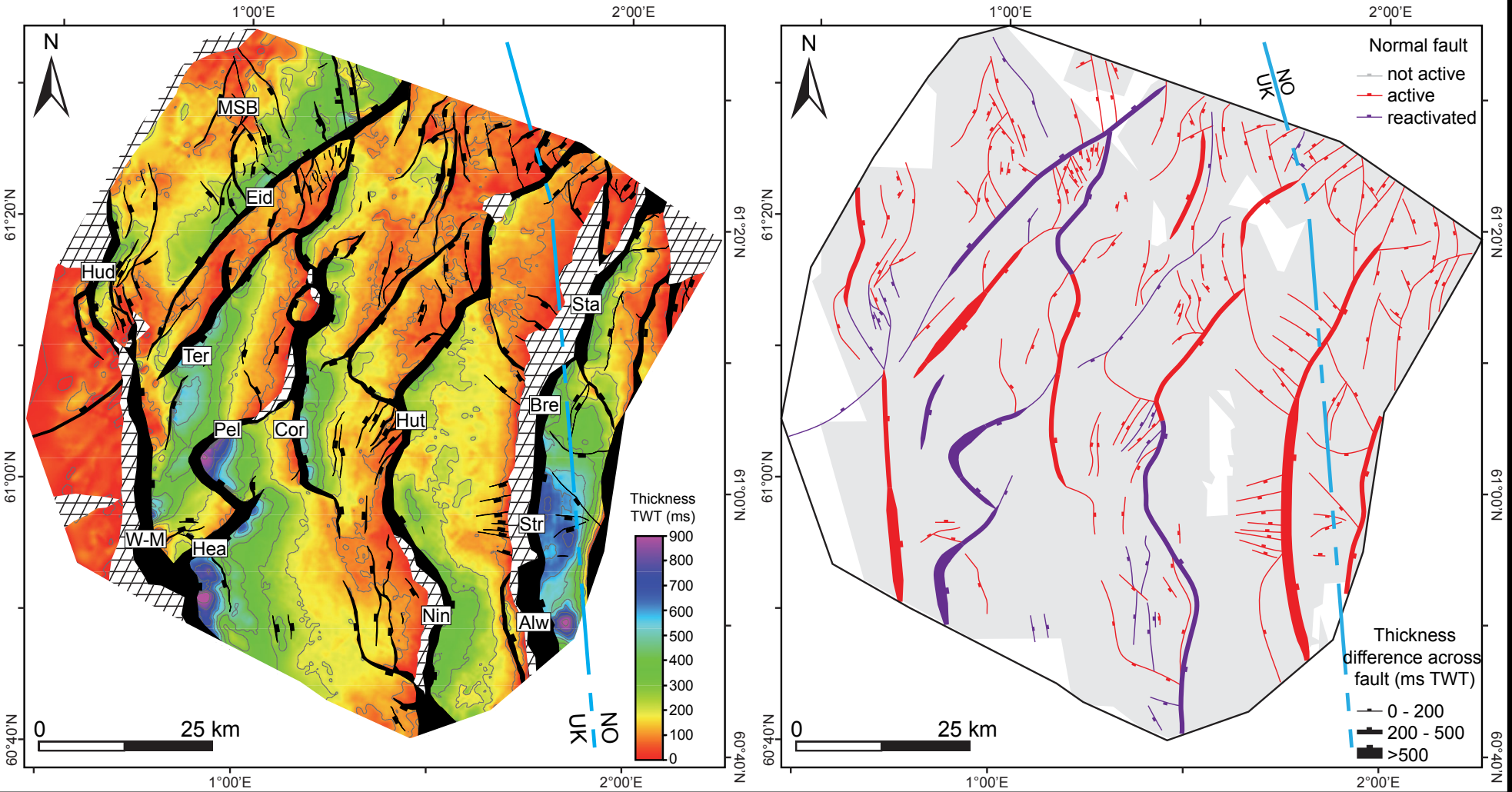


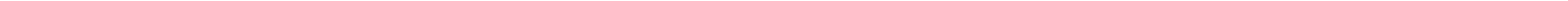


$a)^{F}$

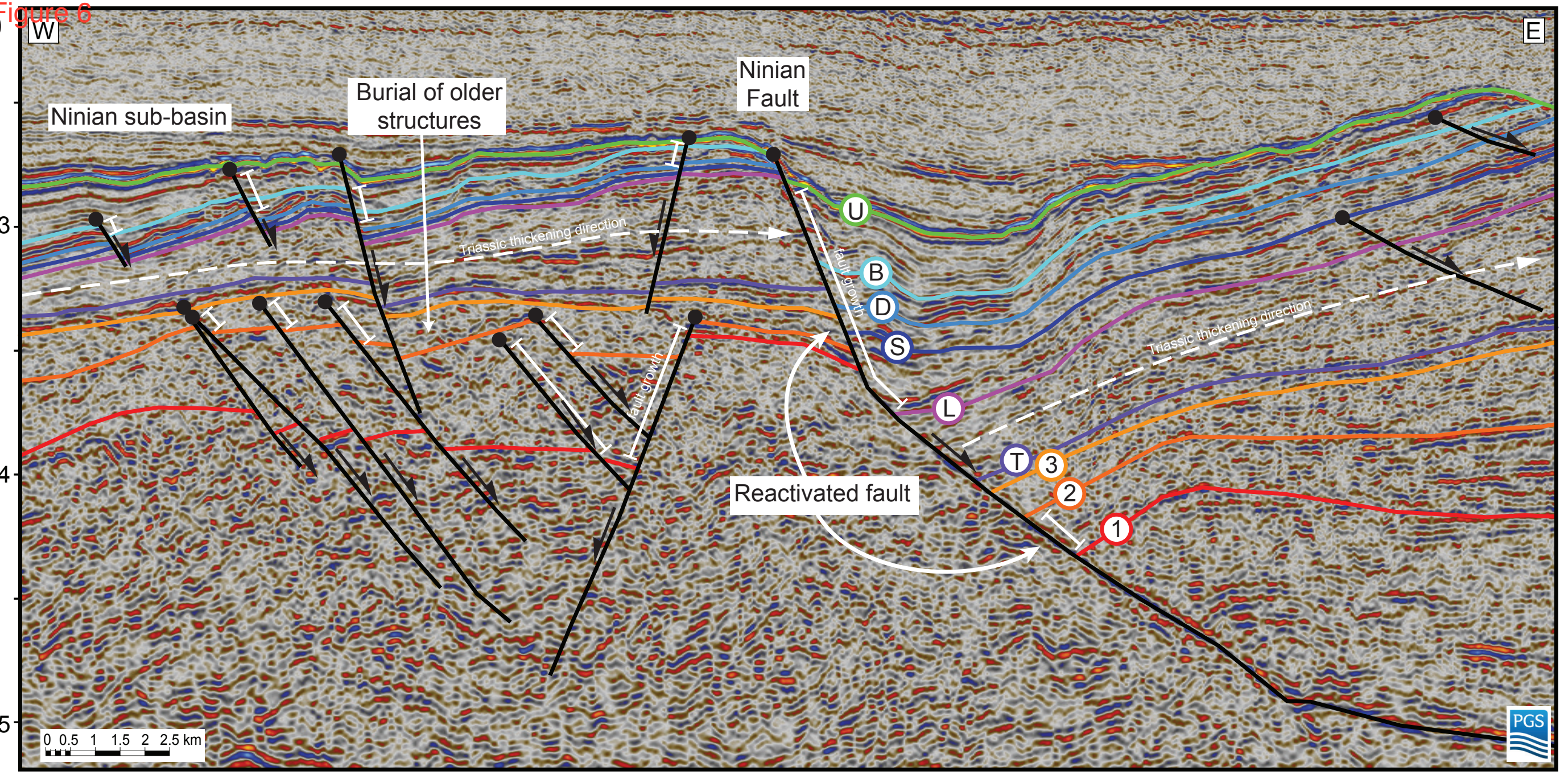

b)

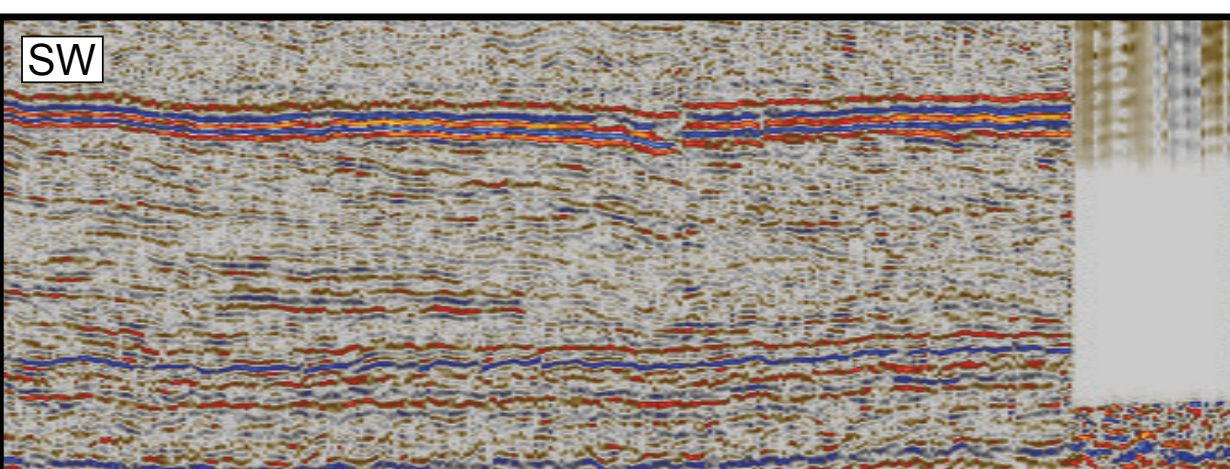

Ninian sub-basin

Ninian
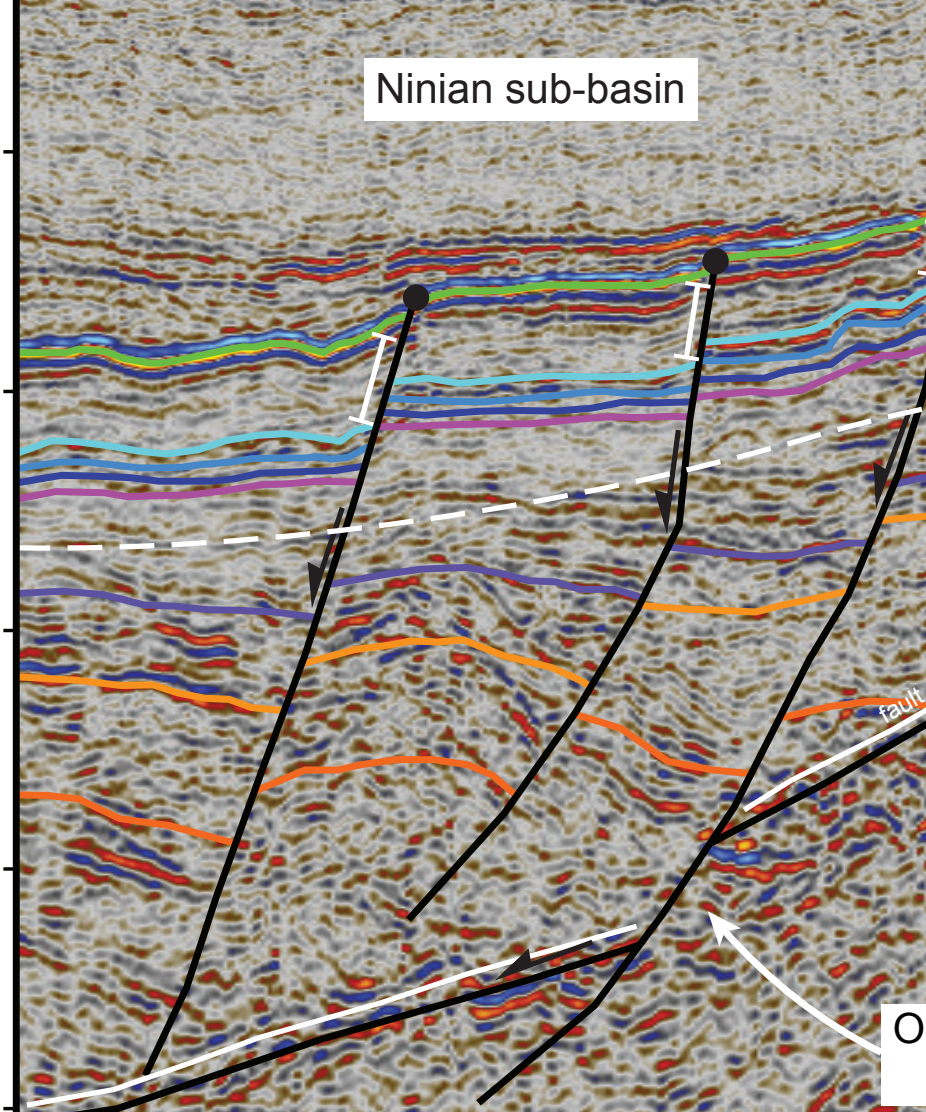

fault cross-cut

by younger fault

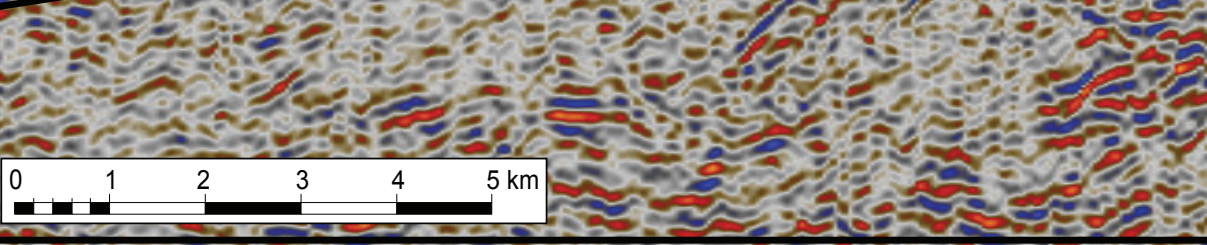

$$
5
$$




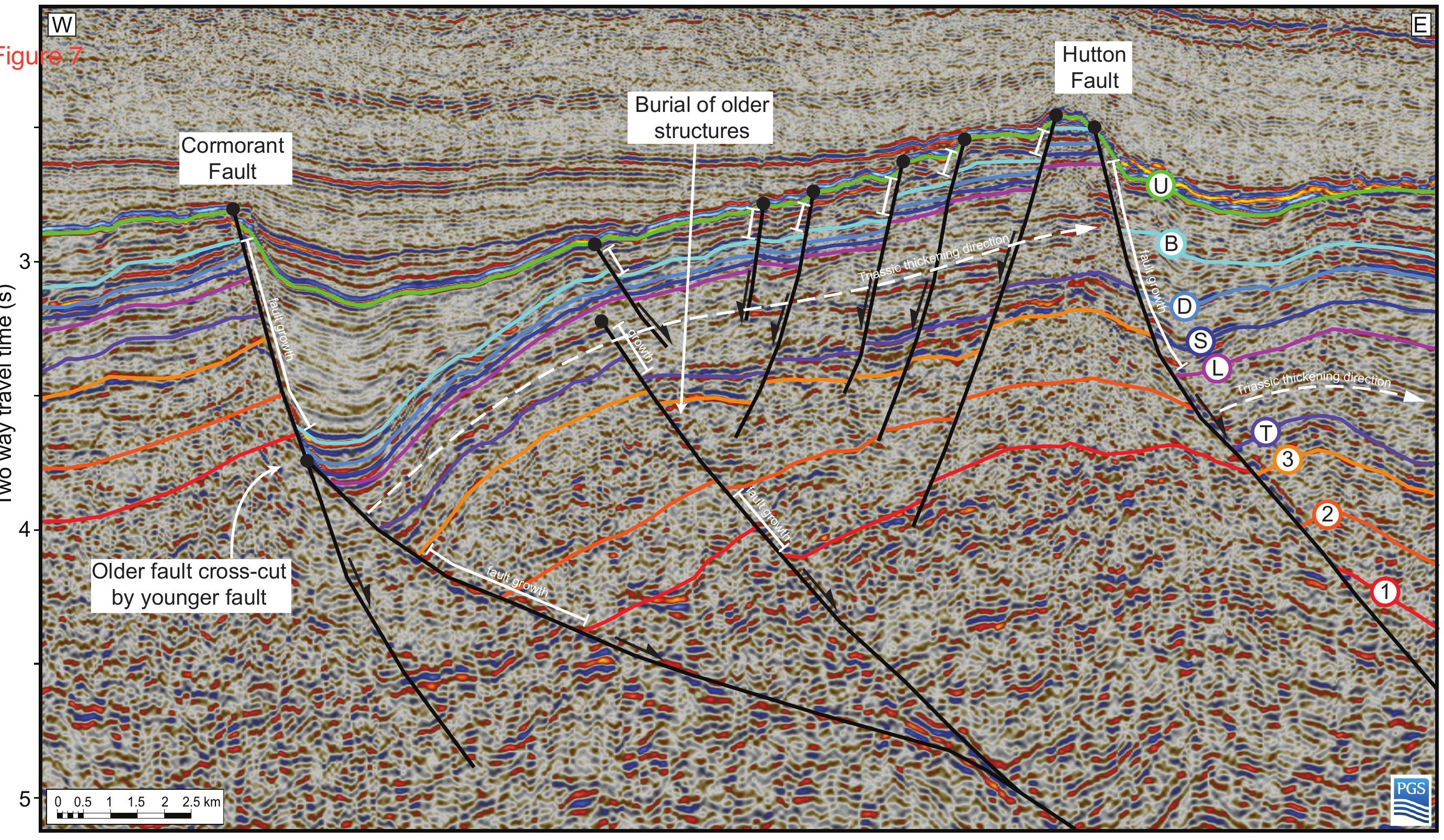




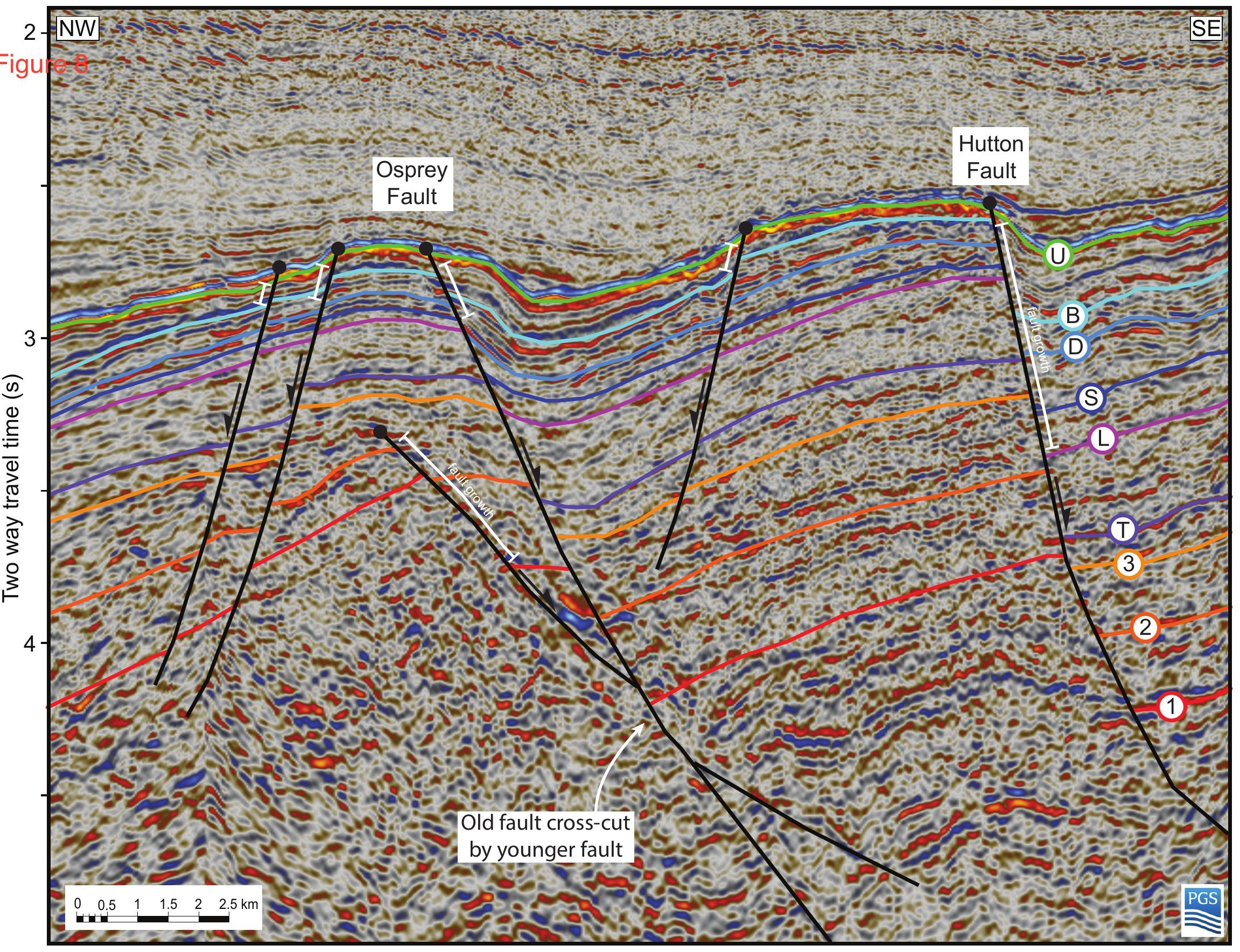


a) Wide rifting across the northern North Sea (Pre-Triassic-to-Early Triassic)
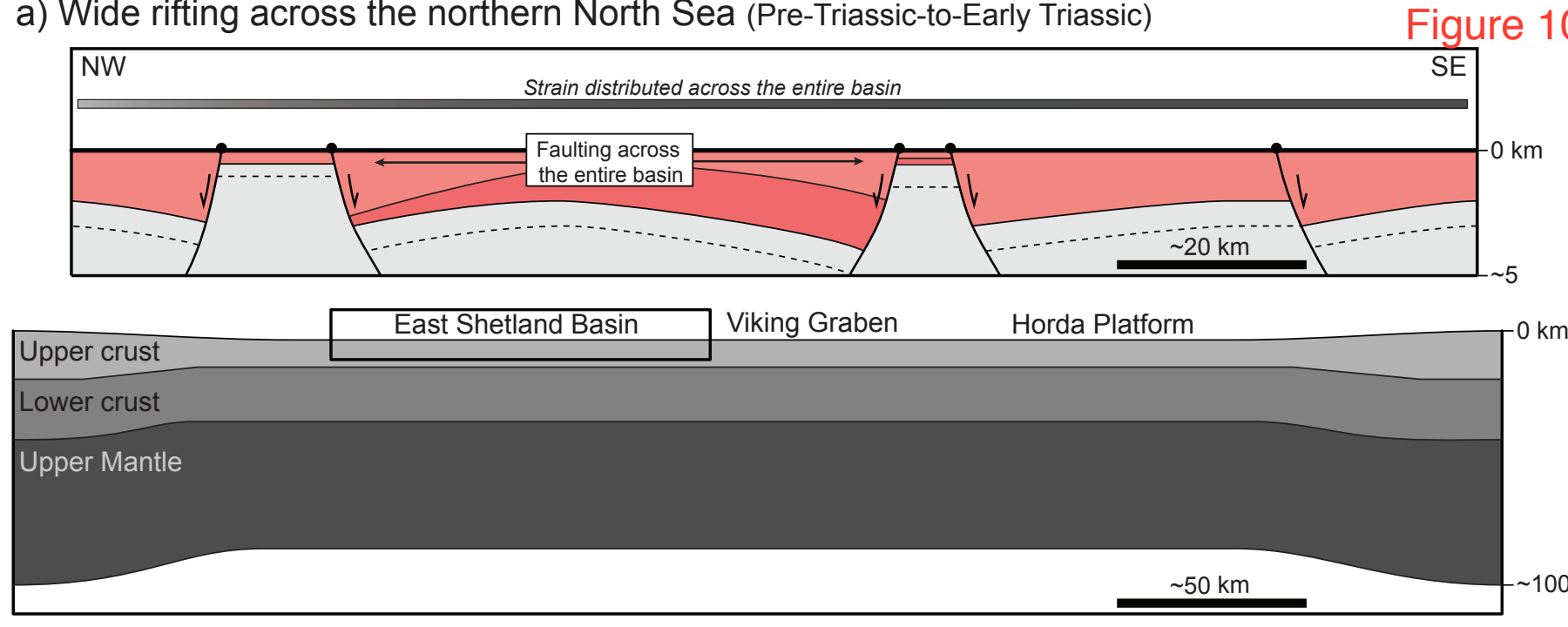

b) Wide rifting with possible focus below the Horda Platform (Middle-to-Late Triassic)
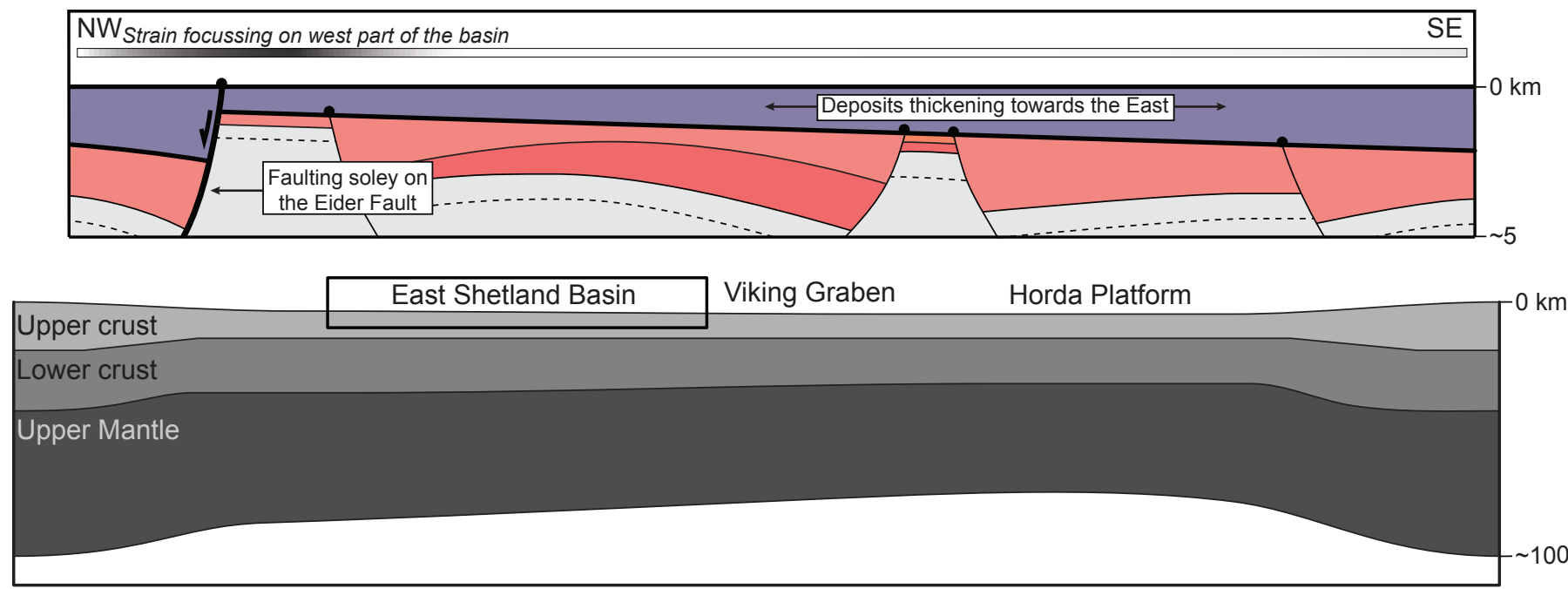

c) Rift narrowing with rift axis below the Viking Graben (Latest Triassic-to-Middle Jurassic)
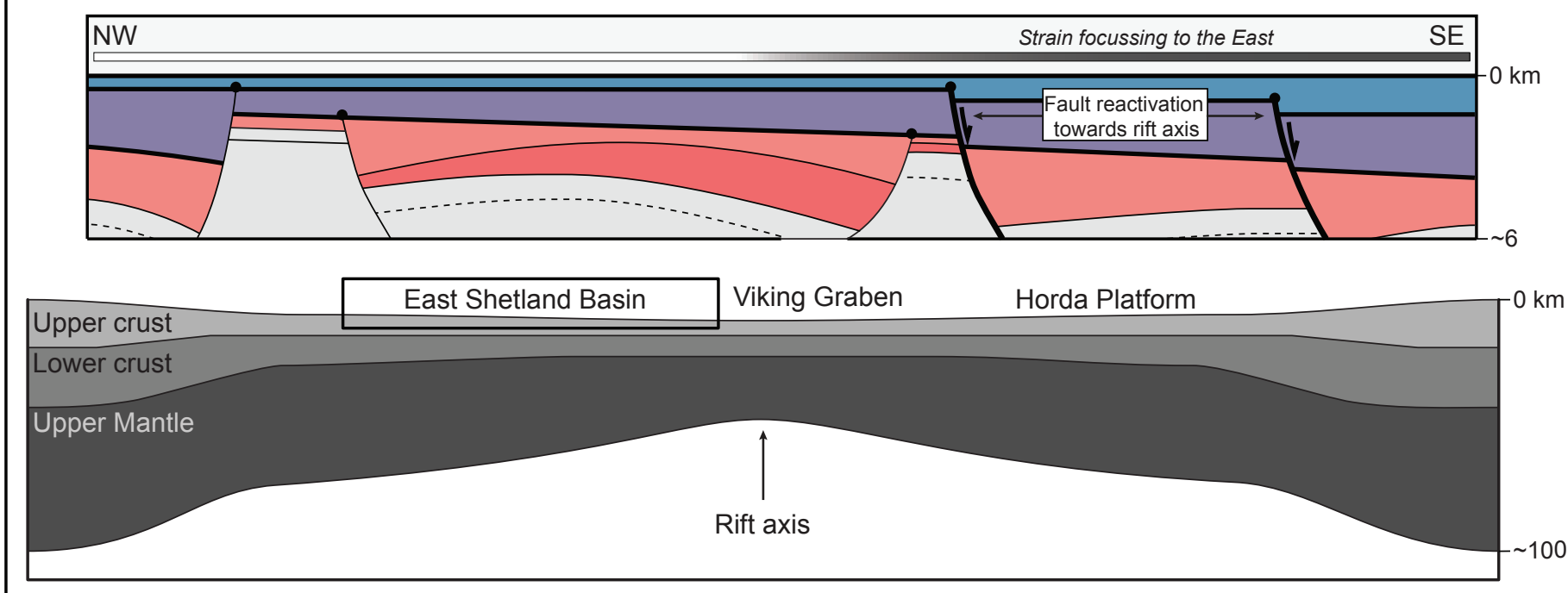

d) Narrow rifting with rift axis below the Viking Graben (Late Jurassic)
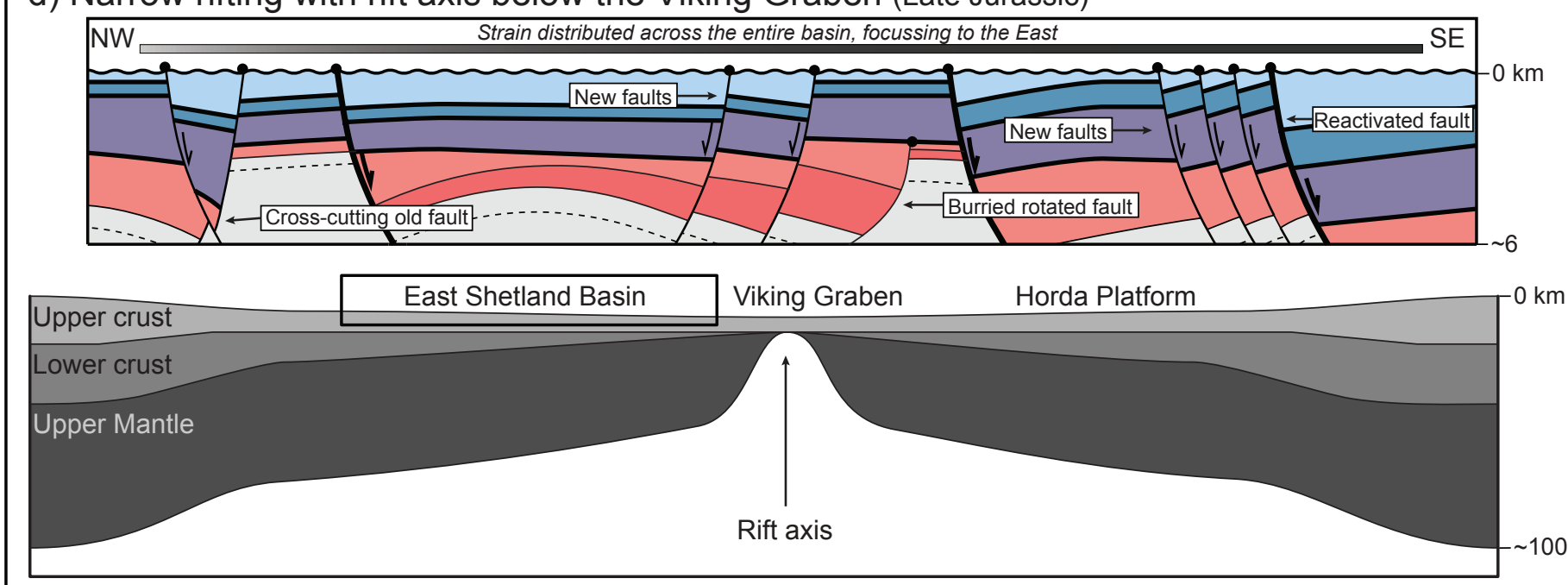

$\square$ Pre-Triassic $\square$ Pre-Triassic Unit $1 \quad \square$ Pre-Triassic Unit $2 \quad \square$ Fault

$\square$ Triassic $\square$ Early-to-Middle Jurassic $\square$ Middle-to-Late Jurassic $\quad \mathbf{\nabla}$ Reactivated Fault

High Relative strain distribution across the East Shetland Basin 